University of South Carolina

Scholar Commons

Fall 2001

\title{
Reconstruction Corruption and the Redeemers' Prosecution of Francis Lewis Cardozo
}

W. Lewis Burke

University of South Carolina - Columbia, wlburkej@law.sc.edu

Follow this and additional works at: https://scholarcommons.sc.edu/law_facpub

Part of the Law Commons

\section{Recommended Citation}

W. Lewis Burke, Reconstruction Corruption and the Redeemers' Prosecution of Francis Lewis Cardozo, 2 Am. Nineteenth Century History 67 (2001).

This Article is brought to you by the Law School at Scholar Commons. It has been accepted for inclusion in Faculty Publications by an authorized administrator of Scholar Commons. For more information, please contact digres@mailbox.sc.edu. 


\title{
Reconstruction Corruption and the Redeemers' Prosecution of Francis Lewis Cardozo
}

\author{
W. LEWIS BURKE
}

\begin{abstract}
This essay recreates in detail the 1877 trial of Francis L. Cardozo, who was state treasurer and a leading African American political figure in Reconstruction South Carolina. Cardozo's trial and conviction provides a quintessential example of the white Redeemers' racially perverted reaction to the supposedly systemic corruption of the state's Reconstruction government. The essay reveals how much the prosecution of Cardozo was motivated and permeated by racial and political motives. The detailed examination should encourage a re-evaluation of the history of Reconstruction corruption in the South, and of the Redeemers' reaction to it.
\end{abstract}

We have been cheated out of our rights for two centuries, and...I want to fix them in the Constitution in such a way that no lawyer, however cunning or astute, can possibly misinterpret the meaning. If we do not do so, we deserve to be, and will be, cheated again. Nearly all the white inhabitants of the state are ready at any moment to deprive us of our rights, and not a loop-hole should be left that would permit them to do it constitutionally.

Francis L. Cardozo

The 1877 trial of Francis Lewis Cardozo, his conviction, and subsequent pardon present a prime example of the racially 1 perverted system of justice that prevailed in the postReconstruction South, and reveals the reaction of the white Redeemers, after they ascended to power, to the allegedly systematic corruption of Reconstruction government. To the historian familiar with Reconstruction and its demise, Cardozo's conviction is not surprising, but the detailed history of the case remains untold. Cardozo's trial received extensive attention in an unpublished 1949 undergraduate thesis (which relied, however, almost exclusively on one newspaper's accounts of the proceedings), and a paragraph of coverage in a 1961 article by Edward F. 
Sweat, 'Francis L. Cardoza [sic] - Profile of Integrity in Reconstruction Politics.' Although a more critical analysis of some of the original evidentiary sources was made by Joel Williamson in his After Slavery: The Negro in South Carolina During Reconstruction, 1861-1877, published in 1965 , there has never been an in-depth analysis of this or indeed any other Reconstruction corruption trial. Examining the trial of Francis Cardozo, therefore, should encourage scholars to begin a full re-evaluation of the history of Reconstruction corruption. ${ }^{2}$

Cardozo's trial was the first and most important in a series of three political show trials intended by the South Carolina Redeemer Democrats to prove the charge that Reconstruction was legally and morally corrupt. The three resulting convictions were the only ones obtained by the Redeemer Democrats in their massive post-Reconstruction investigation. The subsequent pardon of Cardozo was only granted by the Redeemers to free Ku Klux Klansmen and other whites who had terrorized African American citizens of the state as they exercised their civil rights. Cardozo's conviction was a personal tragedy not only in the staining of his reputation, but also in that he was the lone South Carolina Reconstruction politician to serve any significant time in jail. The conviction was a great symbolic victory for the Redeemer Democrats, as they were able to lay claim to the charge that all African American and Republican officials were crooks and scoundrels and thus perpetuate for decades the myth of the depravity of Reconstruction governments in the South. ${ }^{3}$

In fact, Cardozo was so vilified that he became the inspiration for black leader Silas Lynch in D.W. Griffith's film, Birth of a Nation, which was based upon Thomas Dixon's 1905 novel The Clansmen. A review of The Clansmen verifies the conclusion that Cardozo was the model for the villain, Lynch. The story was set in South Carolina, and Silas Lynch was a college-educated missionary, a mulatto, the head of the Union League, the owner of a summer home near Charleston, a great orator, a man of imposing physical presence, and the most powerful black man in the state. All of these characteristics match Cardozo and no other South Carolina political figure of the times. Further confirming the belief that Cardozo was the model for Lynch is the evidence from a Columbia, South Carolina newspaper which thought it ironic that the 'Clansman' was being produced in Washington, D.C. at the same time a public school in the district was being named for Cardozo. It is undeniable that Griffith's fallacious film - with its infamous climactic scene in which the white female heroine is rescued by the Klan from the sexual assault of the black Cardozo figure, Silas Lynch - helped to immortalize many racist fables about Reconstruction in the popular mythology of American culture. The film was also instrumental in the resurrection of the Ku Klux Klan in 1915. Prior to Birth of a Nation even the racist histories had 
portrayed the story of Reconstruction as one of simple political corruption, but as a result of the film's huge success and the wide dissemination of Dixon's novels the story metamorphosed into one of sexual perversion. The popular, racist culture of the times began to assume that rampant sexual depravity characterized Reconstruction, even though there appear to be no recorded cases of sexual assaults of white women by black political figures during that period. Whereas modern scholarship has thoroughly debunked the racist sexual mythology of Birth of a Nation, however, the mythology of political and financial corruption is still a mainstay of the legal history of Reconstruction. ${ }^{4}$

These images of political corruption have also been perpetuated by early historians, who fixed on the notion of the 'prostrate state.' They assumed that all Republican office-holders in Reconstruction South Carolina, including Cardozo, were corrupt, lining their pockets with embezzled state funds. Some modern historians have appropriately pointed out that what Reconstruction corruption occurred in the South was in keeping with the norm for the American political culture of the era, which involved both whites and blacks, Democrats and Republicans. ${ }^{5}$

The trial of Francis Cardozo presents a unique opportunity to reexamine Reconstruction corruption. Cardozo did not flee from prosecution. He did not plea bargain, and even after his conviction, he rejected a pardon, choosing instead to try and vindicate himself with an appeal. There is a wealth of material from which to examine his case. Using the indictment against Cardozo, one prosecutor's trial notes, the purported 'diary' of the chief prosecution witness, Cardozo's appellate brief, newspaper accounts, and the governor's pardon file, as well as other documents and letters, this article will examine Cardozo's trial and conviction in depth.

These source materials reveal the various intersections between politics and justice in Reconstruction and Redeemer South Carolina. Often bizarre, and continually shifting, these connections and disconnections do not lend themselves to easy analysis. Conundrums abound. How and why was Cardozo, perhaps the most influential African American in the state, an impeachment target in 1875 by members of his own race and his own party? And why, after the Compromise of 1877 when Redeemers took power, would prominent white Democrat politicians, who had supported Cardozo during his impeachment in 1875, help obtain Cardozo's conviction for corruption two years later? Why would these conservative whites join together with corrupt Republicans to prosecute Cardozo? Why were some of these corrupt Republicans rewarded for their cooperation? Was Cardozo targeted because of his leadership role? If so, why was he pardoned in 1879 with the support of 
some of his chief adversaries, even though his trial had been the centerpiece of the Redeemers' systematic campaign against Republican officials, and his conviction one of their greatest legal victories?

\section{Cardozo's Background}

Francis L. Cardozo was born in 1836 in Charleston, S.C. to a 'free woman' of color and a Jewish father. He attended schools for the free African American community in Charleston. Trained as a carpenter and shipbuilder, he saved enough money to travel to Scotland in 1858 to be educated at the University of Glasgow and to study at seminaries in Edinburgh and London. After this stay in Britain, he returned to the United States, was ordained a minister, went to Charleston to teach for the American Missionary Association, and founded Avery Normal Institute. Avery became the major school for preparing future African American leaders for South Carolina. ${ }^{6}$

Cardozo was soon selected as a delegate to the South Carolina Constitutional Convention of 1868 in which he played a leading role. Following the convention, he was nominated by the state Republican Party to run for secretary of state, and in April 1868, he became the first African American ever elected to statewide office in United States history. In 1872, he was elected treasurer of the state, defeating Niles J. Parker, considered the most corrupt treasurer in state history. Even in a time of economic depression and even though the Republican Party was under vicious attacks for its corruption, Cardozo's election was not surprising. Throughout his political career he had enjoyed a reputation for honesty. A reform party had been established in 1870 to run against the Republican ticket. Although this group was dominated by white conservatives, it had nevertheless nominated Cardozo as its candidate for lieutenant governor because he was an 'honest, capable colored man.' However, Cardozo declined the nomination and remained loyal to the Republican Party. Early in his political career he had resigned from the advisory board of the state land commission to protest graft in that agency. When, as secretary of state, he gained control of the land commission, he reorganized it and is credited with eliminating the thievery that had been rampant there.

Throughout Reconstruction, white conservatives had used the charge of corruption as their rallying cry to justify Klan violence and political attacks against the Republicans. So-called taxpayer conventions in 1871 and 1874 had condemned state government as 'loathsome' and full of corruption and fraud. In 1872, when Cardozo was elected state treasurer, Republican Franklin J. Moses, Jr. was elected governor. Moses was a South Carolina native, ex-slave owner, Confederate veteran, and the person who 
claimed to have lowered the stars and stripes at Fort Sumter. Historians seem unanimous in believing that the junior Moses was one of the most corrupt politicians during Reconstruction. But, as state treasurer, Cardozo's performance drew praise from both Republican and Democratic newspapers. In one instance, he foiled an attempt by Governor Moses to steal $\$ 25,000$. With the election of D.H. Chamberlain in 1874 , Cardozo had a governor as determined as he to rid the state of corruption. As state treasurer Cardozo could not stop all corruption, but he tried to tighten the state's purse strings. ${ }^{8}$

Those legislators aggrieved by his tight money management soon brought impeachment proceedings against Cardozo. One newspaper opined that the 'treasurer has doubtless mortally offended a number of his present accusers by refusing to be a party to their schemes.' The list of charges against Cardozo was lengthy but based on only three issues. First, Cardozo was charged with illegally funding $\$ 978,500$ in state bonds; second, he was charged with paying fraudulent pay certificates; and third, he was charged with paying the legislature out of taxes collected for other purposes. Cardozo prepared a lengthy and detailed four-point letter in his defense which was published in the local press. As to the bonds, Cardozo correctly pointed out that he had inherited the bonded indebtedness problem and had paid valid state bonds pursuant to a legislative bond consolidation plan. He further asserted that the legislative investigating committee had misunderstood how bonds were issued and paid. In reference to the fraudulent certificates, he said he had warned the legislature of their over-issuance, and that pursuant to state law, he had to pay certificates that appeared valid on their face. As to claims that he had paid the legislature out of revenues designated for other purposes, Cardozo admitted that he had done so under advice of counsel and that no account had suffered a deficiency in revenues because of his action. The impeachment failed when reform Republicans and conservative whites in the General Assembly coalesced against it. Governor Chamberlain was quoted as saying that 'to my knowledge [Cardozo] has not done a dishonest act.' The New York Times concluded that though Cardozo had been charged with violating the law, the state had not suffered any loss, and Cardozo had not gained anything by his conduct. ${ }^{9}$

Cardozo was re-elected treasurer in 1874 and 1876. Governor D.H. Chamberlain considered him his 'ablest and wisest adviser.' Cardozo may have been the most powerful African American in South Carolina. In addition to his elected positions, Cardozo was president of the Union League state council, the most influential organization among the African American voters, and a major leader in the Republican Party and in Governor Chamberlains' campaigns and administration. Cardozo had 
probably been the mastermind behind the integration of the University of South Carolina and certainly was mentor to many of the African Americans who enrolled in the university and its law school. In fact, he too attended the University of South Carolina School of Law and graduated in December 1876. He was admitted to the bar by the Supreme Court in April of that year. ${ }^{10}$

Francis Cardozo had achieved an impressive leadership role in public life during Reconstruction. He also maintained his reputation for honesty after the failed impeachment effort. However he could not avoid later repercussions from the prominence he had achieved. The election of 1876 signaled the beginning of the end of Reconstruction and the end of Cardozo's political career. In this election, white Democrats ran their first slate of candidates for statewide offices since the start of Reconstruction. The Democrats nominated ex-Confederate general Wade Hampton and organized the infamous Red Shirts to run a paramilitary campaign of intimidation and fraud to redeem the state for the white minority, based on a similar successful plan used in Mississippi to oust the Republicans. After election day, Hampton claimed victory, but so did the incumbent Republican, D.H. Chamberlain. Hampton's claim to office required the inclusion of returns from Edgefield and Laurens counties; these, however, had been thrown out by the state Board of Canvassers. The board, including Francis Cardozo, refused to certify the fraudulent returns and were jailed for contempt of court. Two days later the canvassers were freed by a federal judge. But even with the stuffed ballot boxes from Edgefield and Laurens, Cardozo had still won reelection as state treasurer.

Only after the Compromise of 1877 settled the Hayes-Tilden presidential election of 1876 was Democrat Wade Hampton able to assume office as governor. In exchange for the electoral votes of Florida, Louisiana, and South Carolina, the Republican presidential nominee Rutherford B. Hayes agreed to withdraw the Federal troops from around the statehouses of South Carolina and Louisiana; the absence of these troops allowed the Democrats in South Carolina to gain control through threats and intimidation. After the removal of the troops, Governor Hampton's private secretary sent Cardozo and other elected African American officials menacing letters demanding that they vacate their offices. In an angry reply, Cardozo accused Hampton of threatening violence and not keeping his word, but he and the others did vacate their offices and relinquish their claims to them on 1 May 1877. Although the threat of violence had ended his career, Cardozo played a conciliatory role in the transition. He advised Governor Chamberlain to withdraw as being in the best interests of the people and to avoid bloodshed, and he arranged an orderly transition of the treasurer's office to his successor. ${ }^{\prime \prime}$ 
Despite his abdication, Cardozo was targeted by the Democrats for prosecution.

\section{Investigation and Indictment}

On 8 June 1877, the new Democrat-dominated legislature appointed a committee to investigate corruption. Prior to this investigation, the legislature had requested President Rutherford B. Hayes to grant clemency to all white Democrats charged with federal crimes involving election fraud and violence against black citizens; Hayes responded by ordering the prosecution of three white Democrats. Hayes' reply began the chess match that consumed Cardozo's life for the next two years. ${ }^{12}$

Cardozo was called before the committee on 19 July 1877 and arrested two days later. The charge was misappropriation of state funds in that he paid a creditor of the state with designated tax revenues. Cardozo vehemently defended himself against this charge in a letter to a Philadelphia newspaper in which he pointed out that the payment to T.W. Price \& Co. for printing had been specifically approved by the legislature. He concluded the letter by noting that 'Price did the work at about onethird the price it had previously cost the State.' Since this charge was nothing more than a new permutation of one of the spurious impeachment allegations, the state needed more charges to try and obtain Cardozo's conviction. So subsequently he was indicted on seven other charges. (These will be discussed below.) Cardozo's prosecution has been described as part of a systematic attempt by the Democrats to 'blacken the reputation of those who governed the state from 1868 to 1877,' and the prosecuting Democratic attorney general, James Conner, admitted that the indictments were intended to 'politically guillotine' the Republican Party. Conner may also have been reluctant to pursue a full airing of all the fraud because many Democrats would have been implicated. One upstate newspaper stated that 'so many leading Democrats (Fusionists) are implicated in the revelations made before the committee, that an organized effort, having the sanction of the highest authority, is being made to suppress the whole matter, and let the prosecutions already begun against Republicans hang over them as an inducement to leave the State and hush their mouths concerning their Democratic accomplices. ${ }^{13}$

Although some local politically motivated prosecutions were instigated, the legislative investigation resulted in fewer than 20 Republicans being indicted, and only three being brought to trial. Numerous factors coalesced to place these three on trial. It was no coincidence that the South Carolina Democrats tried three Republicans after President Hayes ordered the prosecution of three white Democrats. 
Cardozo's political power, his role as an election commissioner in 1876 , and his reform efforts against legislative corruption, made him an ideal symbolic target for the Democrats and a desirable one for those who wished to seek revenge. Some of those indicted were protected by immunity agreements, resignations from public office, and flight, but Cardozo was a proud man who refused to cooperate or run and insisted on being tried. Frustrated that no major figure in Reconstruction corruption was going to be tried, one newspaper opined that until a major carpetbagger could be had, 'Cardozo is our speciality."14

In addition to Cardozo, Congressman Robert Smalls and former congressman and newspaperman L. Cass Carpenter were tried. The exslave Smalls was a Civil War hero and the representative from a heavily African American district. The Democrats had systematically forced the resignations of virtually all Republican office holders, but Smalls, one of three remaining black congressmen, not only refused to resign but also remained extremely popular with the voters and the Republicans in Congress. Carpenter was a white Republican from the North, a newspaper owner and a very short-term congressman who was especially disliked by the press. His testimony about the fraud and violence of the Hampton campaign before congressional committees investigating the 1876 election helped lead to the indictment of a number of Hampton's supporters, including the three who President Hayes had ordered tried. ${ }^{15}$

So the three men tried and convicted were two black and one white Republicans. Despite the Democrats' constant complaints about the corrupt carpetbaggers and scalawags, not a single scalawag nor prominent carpetbagger was brought to trial. With Cardozo, Smalls, and Carpenter, the Redeemers had the three men they needed to convict.

The first six counts of the indictment against Cardozo were related to consolidated state bonds and had been the basis of the claims made against him in the impeachment effort of 1874 . These charges were also the subject of serious political infighting. One newspaper reported that many Democrats in Charleston held these consolidation bonds and that Governor Wade Hampton supported the policy of validating all of them. The seventh count was yet again the claim that Cardozo had improperly paid the legitimate state debt to the T.W. Price company for printing. In addition to his previously mentioned letter to a newspaper defending his conduct on this claim, Cardozo had said in his treasurer's report to the Legislature for 1875 that while he had been following a liberal interpretation of the Act allowing him to temporarily borrow from one account to pay a debt on an account with a deficiency, if the legislature desired that a strict construction be used he urged them to enact the appropriate legislation. Of course, a similar charge of improper payment 
had failed in 1874. So the only new charge against Cardozo was the eighth count, which charged Richard H. Gleaves, Samuel J. Lee, Josephus Woodruff, A.O. Jones, and Cardozo with conspiracy to cheat by means of a fraudulent legislative pay certificate for $\$ 4,000$ in favor of C.L. Frankfort, a fictitious person. Richard $\mathrm{H}$. Gleaves had been lieutenant governor and presiding officer of the state senate, Lee had been speaker of the state house of representatives, Jones was clerk of the state house of representatives, and Woodruff was clerk of the senate. Although charged with multiple counts of fraud, Woodruff was not compelled to resign from his job as senate clerk until after the trials of Cardozo, Smalls, and Carpenter. Lee, Jones, and Woodruff turned on Cardozo, and Gleaves fled. ${ }^{16}$

\section{The Trial}

After posting bond and moving his family to Washington, D.C., Cardozo returned to Columbia in early October 1877 to help with his trial preparation. On 5 October, he was reported to be in the state treasurer's office at work on the state's financial records. But his bail was unexpectedly withdrawn, and he was immediately jailed. On the 30th of October the attorney general announced that Cardozo was to be tried only on the new charge, the Frankfort certificate count. Over his lawyer's objection that he needed more time to defend against this count and to obtain witnesses who were abroad, the judge set the trail to begin two days later on 1 November. The trial received attention in the major national and regional newspapers, and its importance in South Carolina was borne out by the local press' extensive coverage and such gleeful headlines as "Cardozo caged."17

\section{The Defense and the Prosecution}

Cardozo's only lawyer was Samuel W. Melton, former attorney general, Confederate veteran, former slave owner, and dedicated Republican. Melton faced an array of lawyers for the state. The lead prosecutor was Attorney General James Conner, a United States Attorney before the Civil War and an authority on South Carolina legal procedure. But Conner was more than just a capable lawyer. He was dedicated to the redemption of South Carolina. He had served as a Confederate general during the Civil War, and had been the state leader of rifle clubs used to intimidate black voters during the 1876 election. Apparently Conner and his law partner W.D. Porter were among a group of native whites who had benefited from the work of the infamous 'Railroad Ring' in the early years of Reconstruction. While Conner had the manners of a Charleston gentleman, he was considered by some 'the very quint-essence of concentrated hate and malignity.' ${ }^{\prime}$ 
Conner was assisted by Assistant Attorney Generals LeRoy F. Youmans, Charles Richardson Miles, and L.E. LeConte, and by Solicitor John Abney. Youmans later succeeded Conner as attorney general. Some identified Youmans with the most racist element of the Hampton campaign. Charles Richardson Miles was an experienced prosecutor beginning his career as an assistant attorney general after his admission to the bar in 1851 . He was the Confederate district attomey for the state during the Civil War. One biographical sketch said his early prosecutorial experience 'fitted him for the leading part he took in the political trials that ensued during the infamous rule of negroes and strangers in the state, and in the overthrow of that government.' LeConte had been admitted to the bar in 1871; he played no active role in the trial of the case. Abney had been admitted to the bar in 1873. As the local prosecutor, he was used to help select the jury. ${ }^{19}$

The presence of Leroy F. Youmans and James Conner across the aisle as prosecutors in Francis L. Cardozo's 1877 criminal trial posed a serious ethical question. Youmans and Connor's law partner, W.D. Porter, had served as defense counsel for Cardozo during his impeachment in 1875; now, two years later, Conner as attorney general and Youmans as assistant attorney general were prosecuting Cardozo on charges similar to those raised during the impeachment. Conner and Porter practiced law together from 1866 through 1875. Porter was a conservative who refused the gubernatorial nomination of the Democrats in 1868 because the party's convention had approved of black suffrage. Did Connor's and Youman's representation of the state in the prosecution constitute a conflict of interest? While there was no direct authority in South Carolina that applied to this issue, the prohibition on undertaking representation adverse to a former client was not new. An early legal ethics commentator, Professor David Hoffman, wrote in 1836 that 'It is a poor apology for being found on the opposite side, that the present is but the ghost of the former action.' By the 1870s, a number of jurisdictions from around the United States had reached a consensus in prohibiting such aisle-crossing representation as that undertaken by Youmans and Conner. ${ }^{20}$

There is no record that Cardozo's counsel objected to the conflict of interest. Did Melton simply not see the objection? Did his prior representation of one of the chief witnesses for the state and his prior service as the attorney general during the impeachment inhibit him from thinking he could object to Youmans and Conner? Did Melton's close friendship with Youmans affect the aggressiveness of Melton's defense? Melton and Youmans had attended college together, and Youmans wrote a eulogistic profile of his friend for a bench and bar book. Of course, a friendly, collegial relationship among the native white members of the bar was not unusual. Did the dearth of South Carolina law on the point inhibit 
Melton from making a motion to disqualify Conner and Youmans? Unfortunately, the questions cannot be answered, and it is far from clear that Cardozo would have gotten any relief even had the issues been raised. ${ }^{21}$

\section{The Judge and Jury}

Although Charles Pinckney Townsend was a Republican judge, he was no friend to Cardozo. Born in South Carolina and educated at South Carolina College, he was admitted to the bar in 1857, elected to the legislature in 1858, and re-elected during the Civil War while serving in the Confederate army. A Democrat-dominated legislature selected him as equity commissioner in 1866, and in 1871 he was elevated to a circuit judgeship by a Republican-dominated legislature. However, Townsend was a Republican in name only. During Reconstruction, one conservative newspaper described the judge as a 'faithful and devoted...son' of South Carolina. After Reconstruction he had practiced law with a number of Democratic politicians and was ultimately re-elected to the legislature as a Democrat. Among his law partners was W.J. McKerall, the editor of a newspaper which declared that the idea of conservatives supporting Cardozo was 'puerile and unmeaning.' Judge Townsend's rulings and remarks throughout the trial indicated that his Republicanism was merely a charade; perhaps he was trying to save his judgeship by helping the Redeemers obtain their conviction. ${ }^{22}$

A review of the trial records reveals that Cardozo's lawyer won only two motions during the trial and lost all evidentiary objections. His first success came early. Melton moved that a juror be put upon his voir dire (questioned by the judge as to any prejudice against the defendant). Melton's second win did not come until the very end of the trial, when the judge granted one of his 13 requests for additional charges to the jury. ${ }^{23}$

Jury selection did not go well for Cardozo. The first two jurors called were black and were peremptorily struck by the state. The next two jurors called were white and when Melton attempted to peremptorily strike them, the judge ruled that the defense could not object to jurors substituted for those struck by the state. Next Melton moved to strike the entire panel of jurors because they had been improperly substituted by the Democrats for jurors who had been properly selected earlier in the year by local Republicans. He lost this objection. With the next juror, Halcott P. Green, Melton successfully overcame the state's objection and had him voir dired by the judge. When no cause for exclusion was established by the judge's questioning, Melton had to strike the juror with one of his five peremptory strikes. Melton used the remainder of his peremptory strikes on the next four jurors, including one who was black. ${ }^{24}$ 
The newspaper accounts reported that the jury was predominantly black and Republican; some said that the jury had as many as eight black members. This exaggeration, one assumes, was intended to convince the country and especially the black population that Cardozo was receiving a fair trial. For example, in a post-trial story, one newspaper specifically said the composition of the jury should allay the fears of black people that the prosecution was for the purpose of obtaining control of the government and depriving blacks of their political leader and their civil rights. The press of the day presumed that the presence of even one black juror would assure at least a mistrial for Cardozo. ${ }^{25}$

In fact, there were six black jurors. But, as will be discussed later, the presence of six white and even one unfriendly black juror would prove sufficient to seal Cardozo's fate. It is disturbing to note that as many as nine of the jurors could not read and write. The majority of the black jurors were laborers likely in the employ of whites. All of the white jurors except possibly one could have been employers of black workers. The composition and the characteristics of the jury are verified by the census, city directories, and even the official report of the attorney general Conner after the trial. ${ }^{26}$

At the end of the first day, Attorney General Conner moved, over defense objections, to sequester the jury, and Judge Townsend granted the request. Given the presence of black jurors, joint sequestration was not easily accomplished. Hotel after hotel refused to house the mixed race group, and late in the evening the sheriff had to call upon the attorney general to make an 'urgent application' to the Columbia Hotel to feed and house them. But the integrated jury did not get to sleep in hotel rooms or eat in the dining room; they were housed in the billiard room of the hotel under the constant guard of the sheriff. This extra vigilance may have been occasioned by a recent 'official misconduct' trial of the county commissioners of Williamsburg County. In that proceeding, after the mixed race jury had announced their guilty verdict, the jury was polled, and when two black jurors said they did not agree with the verdict a mistrial was declared and the two jurors arrested. Sequestration of a jury can prevent tampering from such outside pressures as employers, neighbors, and others. The state made a concerted effort to seat as many white jurors as possible; however, if one assumes that the white jurors in this case were predisposed against Cardozo, it only needed the black jurors to have been persuaded one way or the other. But pressure can also be accomplished from within the jury. With a jury under white guards and populated with white employers, undue influence was clearly possible, both in the jury room and in the billiard room. ${ }^{27}$ 


\section{The State's Case}

James Conner opened the state's case by arguing that 'It involves no nice point of law; no fanciful construction of statues. It is a common, unfortunately too common, case of theft, in taking that which belongs to another. It is one upon the character of which good men cannot think. It is an offense prohibited by a law older far than human statues; a law which finds its first expression in the divine commandment "thou shall not Steal."'28

Conner called as his first witness the former speaker of the South Carolina House of Representatives, Samuel J. Lee. Lee was an African American politician whose father was probably Samuel J. McGowan, a Confederate general and later a state supreme court justice. Lee had served with McGowan during the Civil War and claimed to have been wounded in battle. Despite his power as a Republican leader, Lee had been convicted in 1871 of issuing fraudulent county checks as a county commissioner. He had most recently been the solicitor [or prosecutor] in Aiken, but had resigned at the behest of the investigating committee. Lee was no friend to Cardozo - who had once physically assaulted him - and he had served as counsel to the investigating committee that led to Cardozo's impeachment trial. While Lee had been indicted as a co-conspirator with Cardozo to issue the fraudulent 'Frankfort' pay certificate, he also faced other charges for issuing fraudulent pay certificates of over $\$ 29,000$, and had confessed to stealing even more. Lee suffered no legal ramifications for these indiscretions, and in fact may have been rewarded by the post-Reconstruction white establishment. He was appointed a general in the state 'colored' militia and was the most successful black lawyer in South Carolina in the nineteenth century. Lee made an unprecedented 20 or more appearances before the state supreme court and was frequently victorious against white lawyers, including nearly half of his criminal appeals. ${ }^{29}$

Lee's testimony was anything but straightforward. After preliminary matters, Conner had him identify and read the Frankfort certificate. According to prosecution trial notes, Lee tried to explain the history of the document by stating that in the fall of 1873 , during the extra session of the legislature, Cardozo had informed him of a $\$ 4,000$ surplus in the treasury. According to an apparently verbatim newspaper account, Lee testified that he was informed of the balance after the extra session had ended. On cross, Lee clarified his testimony by vigorously stating that Cardozo had said there was a $\$ 4,000$ surplus in undrawn certificates of indebtedness. ${ }^{30}$

When asked who had told him about the surplus, Lee said 'the President of the Senate,' and then adding as if as an afterthought 'and Cardozo, also.' He then said their agreement was that a certificate would be drawn and divided into five equal parts, with shares going to Lt. Governor 
Gleaves, Cardozo, Lee, A.O. Jones, and Josephus Woodruff, and that Gleaves would have it drawn up at his house. Lee testified that Gleaves had said Woodruff would take care of naming the payee for the certificate. He further claimed that 'between the 8th and 14th of December', he and Gleaves went to Cardozo's house where they were paid by Cardozo in groups of certificates totaling $\$ 800$ each, and that they had joked about what a nice Christmas dinner they would have now. He ended his direct testimony by saying that as far as he knew there was no such person as C.L. Frankfort and that the name had been laughed about as a joke. ${ }^{31}$

On cross examination, Lee conceded that he and the clerk of the house had drawn many fraudulent certificates before, that these certificates were often divided four ways, that many were drawn even before some appropriation bills had passed, and that there was no way to know if certificates were issued in excess of appropriations because their books were never balanced. Lee admitted that Cardozo had warned him that the house officers were over-issuing pay certificates. Lee testified that before he appeared before the investigative committee, he talked with the chairman of the committee, but he was not sure he told him about the Frankfort transaction. ${ }^{32}$

On re-direct, Conner asked Lee about the 'F.L. Christopher' certificate. This fraudulent $\$ 2,000$ certificate had been discovered during Cardozo's impeachment trial, and it had been used to pay the expenses of Republican politicians who traveled to Washington, D.C. in response to white conservatives lobbying in D.C. against the Republican administration in South Carolina. Lee admitted that he could not say whether Cardozo had been involved in the Christopher certificate conspiracy. According to the prosecution's trial notes, Lee said 'F.L. Christopher' was a name 'devised' by Josephus Woodruff. ${ }^{33}$

If anyone had conspired to get Cardozo convicted, it was the star witness for the state, Josephus Woodruff with his shorthand diary. Woodruff had been a reporter, and he was still clerk of the state senate, a position he would not relinquish until December of 1877 . He had worked for the state land commission before it was cleaned up by Cardozo. As the senate clerk and owner of the Republican Printing Company, Woodruff was at the center of most legislative corruption schemes, and one newspaper proclaimed, 'Woodruff is still for sale, but who will buy him?' The state was willing to buy him. In July 1877 Woodruff had testified before the investigative committee and had implicated numerous officials in various fraudulent schemes, but not Cardozo. Soon Woodruff and Jones were indicted for numerous counts of fraud, but Woodruff fled from the state before he could be arrested; however, his flight and destination were well-recorded by the local press, and he was returned to Columbia within 
five days. By 7 August 1877, the state had agreed to terms to obtain the testimony of Woodruff. The deal required Woodruff to forfeit all printing claims of his company; to surrender all state pay warrants he held; to surrender a state note and warrant in the amount of $\$ 139,000$; to convey to the state a lot on Richardson Street in Charleston; to give the state his Adams printing press; to complete his testimony before the investigating committee; and to appear when called as a witness for the state. In exchange, the state would nol pros the indictments against Woodruff and indemnify him from all civil and criminal proceedings. While this deal appeared to require a substantial reimbursement from Woodruff, this may not have been the case. The $\$ 139,000$ warrant had been purchased by Woodruff for $\$ 250$. In addition, Woodruff was allowed to keep his mansion in Charleston, for which he had paid $\$ 10,000$ and to which he had made extensive improvements. ${ }^{34}$

On the witness stand, Josephus Woodruff said that Lt. Governor Gleaves had told him to prepare a pay certificate for $\$ 4,000$ because the state treasurer had advised him there was a $\$ 4,000$ surplus in unexpended legislative appropriations, and that it would be divided five ways. He said that he invented the name 'C.L. Frankfort, and he intended it to mean F.L. Cardozo.' Woodruff tried to clear up the confusion left by Lee's testimony as to whether the conspiracy involved a legislative pay certificate or the issuance of certificates of debt. He explained that he prepared the legislative pay certificate and gave it to Gleaves, and that he next saw it when he gave Cardozo $\$ 2,400$ of his company's certificates of indebtedness in exchange for the certificate. ${ }^{35}$

Woodruff then bolstered his testimony with his diary and his printing company's books. Melton objected to the use of the printing company's ledgers because Woodruff had not prepared them and because the bookkeeper who had prepared them was not available to be examined. But the judge allowed the book to be admitted. The ledger book showed entries of payments to a 'C.L.F.' in a section entitled the 'Sunday School fund'; Woodruff claimed this section indicated 'presents' to public officials. Despite objection by Melton, Woodruff was allowed to read one entry dated 23 December 1873 which recorded a payment of $\$ 9,750$ to 'C.L.F' The witness claimed the entry indicated a payment to Cardozo, but he could not remember any of the particulars of why he would have paid the sum to that individual. Also this supposed bribe was not recorded in his 'diary.' The cash receipt book also contained entries which were supposed to indicate credits to Woodruff and Jones of $\$ 800$ each from the Frankfort certificate. ${ }^{36}$

Next came testimony through Woodruff's diary, a little brown book in shorthand. According to Woodruff, he had invented this shorthand and only one other person could read it. However, a modern examination of 
surviving shorthand notes from his work as clerk of the senate has revealed that the shorthand can be read by persons trained in either Pitman or Gregg methods. Melton objected to the diary, but Judge Townsend ruled that the witness could use it to refresh his memory. Under South Carolina legal precedent, a witness having memory failure could refresh his memory from contemporaneously prepared notes and testify from his refreshed memory. But Woodruff had no memory failure, and the court still allowed him to read his translated diary excerpts to the jury, thus admitting them into evidence. These excerpts were from a 'translation' of the diary Woodruff had prepared for the legislative investigation committee after weeks of work in September 1877. In October, when Melton sought to inspect the records of the committee, the chairman refused his request. It is clear that these translations would have been an immense help to Melton in his trial preparation. ${ }^{37}$

The shorthand diary has not been found, and the only available portions of Woodruff's translation cover the periods from July to October 1874 and from August 1875 to December 1876, except for some earlier excerpts that were printed by the joint investigative committee and which date from January 1873. Most of the diary entries introduced into evidence are missing, which led historian R.H. Woody to the view that they were never returned by the printer. Considering that the state refused access to the diary to Melton and that the portions covering the time period of January to July 1875 are missing, there is fuel for a more sinister explanation. By early 1875 the effort to impeach Cardozo had begun in earnest. Woodruff's animosity toward Cardozo is documented in many places in the surviving diary translation, which leads one to speculate that he had been one of the leaders in the effort to impeach Cardozo. Historian Joel Williamson questioned the veracity of the translation in After Slavery, suggesting that it had pagination errors and used terminology that would not have been current when the original diary was supposedly written. In fact, Woodruff was translating the diary at a time when he was still clerk to the Democratic-controlled senate. The translation uses the term 'Democrats' and suggests that his sympathies lay with them even as early as 1874. In 1874 Woodruff was a major behind-the-scenes leader in the Republican-controlled legislature. Moreover, as Richard Zuczek points out, the term 'Democrat' had fallen out of favor during Reconstruction and did not enter in common use again until early 1876 . So one must wonder how much of the translation Woodruff invented. If these missing portions of the diary or even any of the original diary had been available to Melton, his cross-examination of Woodruff might have been devastating. ${ }^{38}$

Even so, Melton's cross-examination was effective. Woodruff replied 'Yes sir' to Melton's first question, 'You had a great many fraudulent 
transactions?' Woodruff had to admit that his 'large business' of fraud as clerk dated from 1868 and that during every session of the legislature he had issued at least $\$ 100,000$ in fraudulent pay certificates. Then came a startling revelation. On direct, Woodruff had used the books of the printing company to establish two $\$ 800$ entries of payments to him and Jones, confirming they had gotten their share of the Frankfort certificate. But Melton demonstrated with a magnifying glass that the Woodruff entry had been altered by the insertion of the number 'eight' in a handwriting that Woodruff claimed was unfamiliar and that the Jones entry appeared to have been entirely inserted in the same unfamiliar handwriting. ${ }^{39}$

As the cross continued, Woodruff admitted he had been told by Gleaves that Cardozo was reporting a $\$ 4,000$ balance in the legislative appropriation, and that while it was Woodruff's job to inform Cardozo of the amount of certificates drawn by the legislature, he never did so; thus there was no way for Cardozo to know whether a surplus existed. Melton concluded this series of questions by commenting, 'Well, suppose I were to tell you that at that time not one cent had been drawn?'40

Then Melton asked Woodruff if he had not tried to bribe Cardozo with a legislative certificate payable to R.T Merriam and endorsed by Gleaves, Lee, Woodruff, and Jones in the amount of $\$ 5,000$, shortly after Cardozo took office in January 1873. Woodruff admitted he had brought the Merriam certificate to Cardozo, and Woodruff claimed Cardozo had tore it up; he denied 'positively' that Cardozo had demanded of him that he write 'cancelled' on the certificate and sign it. Then Melton dramatically produced the certificate, and Woodruff said, 'I take it all back' and admitted that he had signed and cancelled the certificate. ${ }^{41}$

Continuing, Woodruff acknowledged that Cardozo had refused to pay $\$ 90,000$ in certificates of indebtedness to his printing company as authorized by the legislature in 1873-74, and that after Cardozo refused a bribe offer of 20-25 percent, Woodruff had unsuccessfully sued him to force payment to the printing company. Because Cardozo fought the printing company all the way to the U.S. Supreme Court, Woodruff was never paid, despite an order requiring payment by the state supreme court. ${ }^{42}$

The final witnesses for the state's case in chief were minor. One, James D. Wells, a clerk in the treasurer's office, gave some very confusing testimony. He apparently tried to explain how there could have been a surplus of $\$ 4,000$ in the legislative expenses appropriation or at least how the certificate had been recorded in the books of the treasurer's office. However, on cross Wells had to admit that the legislative appropriation had a surplus of $\$ 74,615$ on the first day of January, 1874 and consequently there was never a $\$ 4,000$ surplus in December 1873 that Cardozo could have proposed stealing. Another minor witness should have been a major 
star for the state. As the clerk of the house, A.O. Jones was the fourth signatory on the Frankfort certificate. But Jones denied any knowledge of the conspiracy and testified that he had first heard of the $\$ 4,000$ certificate in the summer of $1877 .^{43}$

\section{The Defense}

The defense began with Francis Cardozo himself, who recounted how Woodruff had tried to bribe him with the Merriam certificate and then testified that Woodruff 'had made repeated overtures to him in order to try and get payment of his appropriation for printing before the work was done.' Cardozo denied any knowledge of the Christopher certificate and supported his denial of participation in the Frankfort certificate conspiracy by intricately going over the records of the treasurer's office to contradict the two versions of conspiracy presented by Lee and Woodruff. As to the Lee scenario involving certificates of indebtedness for printing, Cardozo demonstrated that the legislature had authorized printing certificates of $\$ 231,996$ and that these certificates were not received until 11 December 1874 and that the entire issue was not received until after Christmas. The American Bank Note company printed $\$ 255,000$ in certificates because the printing plates could not print the odd amount of $\$ 231,996$, and upon receipt of these certificates, Cardozo immediately cancelled the overage. When asked where these cancelled certificates were, Cardozo replied, 'I think they are in the southwest corner of the Treasury on one of the shelves,' and a clerk soon produced them in court. This evidence demonstrated that Cardozo could not have predicted a $\$ 4,000$ surplus of certificates of indebtedness and that in fact no such surplus had existed. As to Woodruff's conspiracy involving a surplus of $\$ 4,000$ in the appropriation for the extra legislative session, Cardozo presented evidence that he could not know if there was a legislative surplus. Although the appropriation was approved on 19 November 1873 , the taxes to fund the appropriation were not levied until 22 December, and according to treasury records only $\$ 385$ was paid out of this appropriation in the entire month of December. By the end of January, 1874 there was still a surplus in this appropriation of $\$ 42,243$. So based on the treasury records there was never a $\$ 4,000$ surplus in the legislative appropriation through at least January $1874 .{ }^{44}$

On cross-examination of Cardozo, the attorney general attempted to obtain an admission that Cardozo knew there were illegal over-issues of legislative certificates. Cardozo admitted that there were over-issues, but that he could 'not know that some were illegal but thought so,' adding that 'he never paid certificates he knew or strongly suspected to be fraudulent.' At this point Conner interjected the inflammatory issue of politics by asking Cardozo to admit that, although he suspected Franklin J. Moses of issuing 
fraudulent certificates as speaker of the house, he had voted for Moses for governor. Cardozo said he voted for Moses because he was the nominee of his party. As a loyal Republican, Cardozo had no other choice in the election of 1872. The only other gubernatorial candidate in that election was James L. Orr, who, as governor during Presidential Reconstruction, had opposed the adoption of the Fourteenth Amendment of the U.S. Constitution and supported some of the infamous 'Black Codes. ${ }^{45}$

Changing subjects, Conner asked Cardozo about transactions with banker Hardy Solomon. Hardy Solomon, who was to be called as a rebuttal witness for the state, was a merchant and banker in Columbia. Through his grocery, Solomon sold liquor and other supplies to Woodruff, who then provided them to the legislators. Solomon had been very active in party politics and at various times had been rumored to be a candidate for governor and treasurer. Even more important was the fact that he had been the state's banker during the Moses administration. His bank, the South Carolina Bank and Trust Company, collapsed on 2 July 1875, resulting in a loss to the state of over $\$ 200,000$. This loss Cardozo had tried to prevent by attempting to withdraw state funds from the bank, but he had been overruled by the board of deposit. Solomon and Cardozo were avowed enemies, and the two had come to blows at one point. Conner tried to get Cardozo to admit that he had advised Solomon to withdraw some certificates for payment that lacked proper documentation and substitute other certificates for the invalid ones. Melton objected to this line of questioning on relevance, but the judge overruled the objection, and Cardozo denied the allegation. Now Conner tried to rehabilitate Woodruff by asking Cardozo to explain why he had kept the Merriam certificate for five years without exposing the officers of the general assembly and the clerks of the two houses and Woodruff. Cardozo responded that although Woodruff had offered him bribes, he had accepted none; and since Woodruff had not gotten any more money than was appropriated by the legislature, Cardozo saw nothing to be gained by turning in Woodruff. ${ }^{46}$

On re-direct Melton introduced a report issued by Cardozo as treasurer admonishing the legislature for the over-issuance of certificates. Continuing, Cardozo testified that Woodruff had sued him because, while treasurer, he followed the advice of the attorney general, S.W. Melton, not to pay the claims of the printing company. Since as defense attorney Melton would not have been permitted to be a witness in a client's trial, this was an ingenious method to put Melton on the witness stand without his testifying. ${ }^{4 ?}$

On cross, Conner had tried to create the impression that Cardozo had been in league with Governor Moses. Cardozo was no friend of Moses, and Melton had not prepared Cardozo for this line of questioning. Therefore, 
his lawyer had to lead Cardozo to recount that he had referred three cases involving county treasurers for prosecution, and that despite convictions, Moses had pardoned two of them. Cardozo also recounted his futile efforts in 1875 to prosecute former state treasurer, Niles J. Parker, but said that Parker had been released by a judge on habeas corpus. There are no reports that Melton had Cardozo tell the jury of his success at thwarting Moses from stealing $\$ 25,000$ in $1872.4^{48}$

Since Conner had crossed Cardozo about Solomon, Melton had to have Cardozo reply to that testimony. First, Cardozo denied that he had ever advised Solomon to withdraw invalid claims and substitute others. Cardozo clarified that Solomon had offered him a bribe of $\$ 5,000$ which he refused, and that he had not paid two bills presented by Solomon because his clerk, T.J. Minton, said they were invalid. Then 'Solomon got mad, and wanted to fight and shoot,' but afterwards Solomon found the valid voucher and 'the Legislature ordered it paid and I paid it."49

Former treasury department clerk T.J. Minton was the only other witness for the defense. Minton testified that as clerk he had usually paid certificates without knowing whether the endorser's signature was genuine; what was important to him was whether the certificates bore the genuine signatures of the appropriate officers of the legislature. Therefore, if the Frankfort certificate had had the appropriate signatures, he would have paid it. Minton said he had paid thousands of 'persons whose handwriting he did not and could not know.' On cross, he said he normally did not bother Cardozo except as to matters of importance and vehemently denied the suggestion by the attorney general that Cardozo had told him it was none of his business when Minton questioned a certificate presented by L.N. Zealey, a clerk of Solomon's bank. Minton answered adamantly 'no such transaction occurred. ${ }^{50}$

The defense rested.

\section{The Rebuttal Evidence}

The state began its rebuttal by recalling Josephus Woodruff, who gave evidence that offers the historian two major flaws in the state's case. First, Woodruff said that the $\$ 5,000$ Merriam certificate had been backdated, and that it had really been offered to Cardozo in December 1873, the same month in which the Frankfort certificate was suppose to have been issued. Earlier in the trial, Woodruff had offered the printing company records to claim that he had paid 'CLF' $\$ 9,750$ in the same month. All of this testimony seems incredible. Why would Cardozo refuse a $\$ 5,000$ bribe in the same month in which he was supposed to have taken one for $\$ 9,750$ ? And even more incredibly, why would Cardozo enter into a conspiracy in which his share would have been only $\$ 800$ ? Next, Woodruff read from his 
diary a lengthy list of instances in which he claimed he had paid money to Cardozo. Woodruff stated vehemently that only on one occasion had he offered a fraudulent certificate to Cardozo and that was the Merriam certificate. Then Woodruff added, 'I paid him in percentages of our appropriations in currency.' Conner then asked him, 'No checks passed between you, and you always paid him in currency?' To which he answered, 'Yes, sir.' When asked if he had any means of proving that, Woodruff read the 13 January 1873 diary entry, which he claimed said 'I paid Cardozo $\$ 3,000$ in currency.' Amazingly, one of the few surviving diary 'translations' used at the trial is the entry for 13 January 1873. This entry does not contain the words 'in currency,' and in fact it states that Woodruff had a check for $\$ 3,000$ for Cardozo. So to cover deficiencies in the state's case, Woodruff conveniently invented the words 'in currency' and did not read his own 'translation' that said he had a $\$ 3,000$ check for Cardozo. ${ }^{51}$

The state then re-called A.O. Jones. Jones had denied any involvement in the Frankfort conspiracy when first called as a witness. $\mathrm{He}$ now testified that Woodruff had told him that Cardozo had taken $\$ 12,000$ or $\$ 15,000$ from Woodruff and Jones after passage of an appropriation of $\$ 250,000$ and that Cardozo had regretted to Jones that he had ever taken any money from them..$^{52}$

As anticipated, banker Hardy Solomon was called by the state in rebuttal. Solomon denied that he had offered a $\$ 5,000$ bribe to Cardozo but claimed he paid other bribes to him. Then Solomon said he presented a claim of $\$ 103,000$ to Cardozo which he refused to pay unless Solomon gave Governor Moses and Cardozo $\$ 35,000$. Solomon's story became confusing in its arithmetic and logic when he explained that in response to this demand he paid $\$ 7,000$ to Moses, $\$ 5,000$ to Speaker Lee, $\$ 5,000$ to Lieutenant Governor Gleaves, and $\$ 3,000$ to Cardozo. Why would Solomon pay $\$ 20,000$ in response to a demand for $\$ 35,000$ by Cardozo and give half to Gleaves and Lee? And why would Cardozo demand $\$ 35,000$ for Moses and himself and settle for $\$ 3,000$ ? On cross, Solomon was forced to admit that he blamed the bankruptcy of his bank on Cardozo, and that Cardozo had always been his enemy. Solomon also admitted that he had not testified about the $\$ 20,000$ bribe before the legislative investigating committee in 1877. The state then re-directed Solomon to assert that he had testified about the bribe before a legislative committee in 1875 . However, on recross, Melton produced Solomon's testimony before that committee, forcing the latter to admit that he had not, in fact, testified that he had bribed Cardozo. However, when Melton tried to use the 1875 report to further impeach Solomon's testimony as to the dollar amount of the alleged bribe, the state objected and the judge sustained the objection. Solomon had testified in 1875 that he had paid $\$ 15-17,000$ to Moses, Gleaves, and Lee, 
but in the trial, he appears to have conveniently added $\$ 3,000$ to his story so that he would have an amount with which to bribe Cardozo. ${ }^{53}$

The state concluded with two minor witnesses. L.N. Zealey, an employee of Hardy Solomon's bank, testified that Cardozo ordered T.J. Minton to pay a fraudulent Solomon claim. The final witness was Senator John Cochran, chair of the investigating committee, who testified that he found the Solomon claims in the treasurer's office. John Cochran was a minor witness for the state in its case in chief and in rebuttal. However, he was not a minor figure in Reconstruction or in the investigation of Cardozo. A native of Abbeville and a Confederate veteran, he had been active in Republican Party politics since 1872, served on the staff of governor Franklin J. Moses, and was elected from Anderson county as a representative in 1872 and as a senator in 1874 and 1876. Despite the fact that Cochran had been implicated in a fraudulent transaction with the state land commission, he was appointed by the Democrat-controlled legislature to chair the Joint Investigating Committee in 1877. Of course, his fraudulent land transaction was ignored in his committee's report. $\mathrm{He}$ had also been tried and acquitted of murder in early 1877 . So Cochran was not a statesman of unblemished reputation. ${ }^{54}$

The case was now closed.

\section{Closing Argument}

On 5 November 1877, closing arguments were heard. Under South Carolina trial procedure, the state was entitled to open the arguments and rebut the defense's arguments. C.R. Miles argued for two hours, S.W. Melton for five, and Attorney General Conner closed in rebuttal for two and a half hours. The only reports of these lengthy orations are summaries in the newspapers. While the newspaper coverage of the trial was often incomplete and erroneous, these press accounts do highlight the respective approaches of the state and the defense. Cardozo's appellate brief also offers some glimpse of the approach Melton may have taken in his arguments. ${ }^{55}$

Miles began by characterizing the state's case as a simple matter of fraud and robbery and then attacked the defense as being based on collateral matters (i.e. politics). Miles provided a long list of his legal authorities, and then returned to the state's original factual scenario that there had been an appropriation of $\$ 75,000$ for the extra session of 1873 , and that 'When all the certificates had been drawn, it was found that four thousand dollars remained undrawn. At the invitation of the treasurer the officers of the two houses met the treasurer in his office, and there it was arranged that a certificate should be drawn for that amount and exchanged for a certificate of indebtedness to the Republican Printing 
Company.' In response to Cardozo's defense that the stories of Lee and Woodruff did not match and that Cardozo could not have known the balance in the legislative accounts, Miles claimed that it did not matter who originated the scheme, that it did not matter whether Cardozo had known what the balance was, that it was not necessary for the conspirators to have received any money, that it was not necessary for the pay certificates to have been actually made or for any overt act to have been committed; all that mattered was that the simple agreement to defraud had been made. He denied that the state's case was political; he said it was based on the testimony of Lee and Woodruff and could never have been proved without Woodruff's diary. ${ }^{56}$

Miles continued to attack the defense by asserting that it was oath against oath, and that Cardozo had no corroboration. Miles maligned Cardozo for testifying in his own behalf, saying that 'the law has only lately allowed the accused to testify in his own case,' and that Cardozo had not explained, only denied. He then defended the state for calling Hardy Solomon as a rebuttal witness, asserting that Cardozo had put his character into question, thus allowing the state to call Solomon. Miles claimed that if Solomon had been truthful, his testimony had convicted Cardozo of not only lying, but also of conspiracy, fraud, and the basest betrayal of the public's trust. Miles ignored the fact that the issues of the Solomon allegations had not been introduced by the defense, but by the state in cross-examination. Moreover, Cardozo was not on trial for any of the claims made by Solomon and had never been legally charged with them. Miles ended by condemning Cardozo for bringing dishonor on his race, state, and religion. ${ }^{57}$

S.W. Melton immediately opened his closing argument with an assault on the political nature of the state's case. The Charleston News $\mathcal{B}$ Courier decried that 'He began with the usual appeal to the feelings of the jury, with a flowery and pathetic description of how history repeats itself, and when one party goes up another goes down, and the rising party ever inscribe upon their banners "Retribution and Revenge." Melton argued that Cardozo, the leader of his party, was being prosecuted while the real thieves had been allowed to escape justice, and he asked what greater proof of innocence there could be than the fact that he returned to be tried. '[Cardozo] would rather run the gauntlet than go to anywhere in the world and have the slow moving finger of scorn pointed at him and those he loves.' Melton continued this argument by advising the jury that Cardozo had instructed him to tell them he did not want their mercy but their justice. While Melton agreed that Lee and Woodruff stole from the state, he stressed that they had exchanged their testimony for freedom, but that the state had not proved that Cardozo had stolen anything. ${ }^{58}$ 
In response to the attack on Cardozo for voting for Franklin J. Moses for governor, Melton admitted that he too had voted for Moses, but said one could not be tried for that. As proof of his client's reform efforts he pointed out that the state debt had fallen from $\$ 21,000,000$ to less than $\$ 7,000,000$ under Cardozo. ${ }^{59}$

Melton challenged the state's claim that Cardozo was responsible for every fraudulent certificate. 'It was impossible for him to know whether the endorsements were true' and when he refused to pay fraudulent certificates he incurred the enmity of all. Melton supported his argument by reading the state statutes that compelled Cardozo to pay any certificate presented to him with the signatures of the appropriate officers. According to one press account, Melton attacked the state's evidence, although newspapers do not reveal the details of his argument. But his appellate brief contained a detailed and meticulous attack on the facts of the state's case, and one would assume that he made these same attacks in his fivehour speech. In particular, the brief picks apart the inconsistencies in the testimonies of Lee and Woodruff. Melton pointed out that Lee was facing life in prison and had traded Cardozo's life for his.own. Felony charges such as those faced by Lee could have resulted in a life sentence while Cardozo's conspiracy charge was only a misdemeanor. As to Woodruff, Melton simply called him, with 'his little whirligig book,' a liar. As to the uncorroborated testimony of Hardy Solomon, Melton said Cardozo could not be guilty of taking bribes when it was Cardozo alone who brought down Solomon's fraudulent bank. ${ }^{60}$

As he concluded, Melton brought his client to tears as he told the jury, 'I grant you I am paid for talking here. Yes; I have taken the very roof that covered the heads of the defendant's wife [and] children to pay my fee, for it was all he had. But I have a feeling of gratitude toward him when I remember how he stood by me in fighting the fraudulent claims against the State. ${ }^{61}$

Attorney General James Conner ended the arguments by accusing Melton of introducing the subject of politics; he then proceeded to assert that the Cardozo defense was based on the theory that former governor Franklin J. Moses was a bigger reformer than Cardozo. Conner next 'dissected [the career of Moses] thoroughly, and showed the shameless frauds that characterized his political administration.' This argument was intended to inflame the political prejudices of the jury, despite the fact that nowhere in the available record can be found any evidence that the defense defended Moses; to the contrary, Cardozo had tried to have Moses criminally charged for his thievery. ${ }^{62}$

Connor then made a series of points that must have been in response to unreported defense arguments. Conner countered Melton's argument 
that Cardozo would not stoop so low as to steal a mere $\$ 800$ by reminding the jury that the Vice President of the United States, Schuyler Colfax, had been shamed by a bribe of the insignificant sum of $\$ 1,000$. This was another specious political attack. As a radical Republican and strong supporter of congressional Reconstruction, Colfax was no hero to white South Carolinians; moreover, the alleged bribe was $\$ 4,000$, and Colfax was never charged nor convicted. Conner asserted that Lee and Woodruff corroborated each other, and denied that the two men had colluded in their stories, because that would require believing that the legislative investigating committee had colluded with them. ${ }^{63}$

Connor next attacked Melton for asking the whereabouts of the bookkeeper for the Republican Printing Company. This argument was unreported, but it is logical that Melton would have asked the question since he had objected to use of the printing company records without their bookkeeper being present to verify them. An angry Conner continued,

Did [Melton] know that Benedict came after the State closed? And if I had offered to put him up when he came, he would have objected to our doing so then because we had not put him up before. I will not tell you whether he was here or not, because I have no right to testify any more than defendant's counsel could tell you what the law is. The law must come from the judge and the facts from the witnesses. The learned counsel has no right to throw his personal influence into the scale in favor of the prisoner... I might as well tell you that you must find the defendant guilty because I believe him guilty ${ }^{64}$

Since the state was entitled to the last argument, the defense had no way to rebut this outrageous implication by Conner that the bookkeeper would have been a witness for the state but had arrived too late. Moreover, trial counsel in South Carolina were prohibited from offering an opinion on any evidence, much less on the guilt or innocence of a defendant. By using this improper back-handed comment about his believing Cardozo guilty, Connor had blatantly defied this prohibition; and again, Cardozo had no way to counter the argument with the jury. ${ }^{65}$

Conner ended his argument with an assault on Cardozo's message to the jury that he did not want mercy. Conner tried to turn the statement into a plea for mercy. He said, 'If he is innocent, mercy is a reproach and a shame... It is only to the erring and the sinful that the claim of mercy goes out. ${ }^{, 66}$

The Judge's Charge, the Verdict, Sentence, and Bail

On Tuesday, 6 November, Judge Townsend charged the jury for more than two hours. The bias of the judge was obvious. The Columbia Register 
provided the most complete account. In it, the newspaper reported that Townsend concentrated on the facts of the case, and spent little time on the law other than to charge the law of conspiracy and inform the jury that Melton had erred in his argument on that issue. The judge charged the facts fully for the state, including the rebuttal evidence, but mentioned none of the discrepancies of the state's case. Ignoring the documentary evidence in support of Cardozo, Judge Townsend opined to the jury that the defense was based simply on Cardozo's denial. He then dissected the defendant's case, pointing out that a misdemeanor could be tried without the defendant present and that therefore it was not remarkable that Cardozo had returned to face the charges against him. Of course, the judge ignored the fact that Cardozo did not know until two days before trial that he was going to be tried only on the misdemeanor count. (No other defendants charged with corruption, such as Gleaves, were tried in their absence.) Since the attack on Cardozo's defense was a judicial opinion on the facts of the case, Judge Townsend appears to have violated the state constitutional ban on judges charging against the facts of a case. ${ }^{67}$

Following the charge, Melton requested the court to make additional charges. A Charleston newspaper reported that Melton used this opportunity to summarize his whole case again while requesting 37 more charges. The newspaper further reported that while Conner protested the irregularity of this tactic, he consented to the additional charges to provide 'the fairest trial that could possibly be had, and that Judge Townsend had proceeded to ram all the new points on top of the old until the jury was full.' In fact, according to Cardozo's appellate brief and the Columbia newspaper, Melton requested no more than 13 charges, and Conner did not consent to any of them. Judge Townsend rejected all of the requested charges except one on accomplice testimony. ${ }^{68}$

The case was now in the jury's hands, but after $11 \frac{1}{2}$ hours of arguments and charge, one newspaper observed, 'the jury was probably at a loss to know who was on trial, the treasurer, the counsel, the judge, themselves or the witnesses. ${ }^{69}$

After 12 hours of deliberations, the jury returned a verdict of guilty. When he heard the verdict, Cardozo's 'eyes became dilated, and his whole visage denoted grief. He was the picture of despair. Melton was almost as visibly affected as he, and without a word they marched out of court together. ${ }^{70}$

According to the press, the verdict 'caused genuine surprise, inasmuch as the public mind was prepared for a mistrial.' There was delight in the white community and dismay in the black. The surprise in the local press's eyes came from the fact that a jury with blacks had convicted the leader of the Republican Party. Probably Melton's greatest blunder came when he 
heard the verdict and did not request to have the jury polled. A unanimous jury verdict was a common law right and had never been abrogated in South Carolina. Melton apparently learned after the fact that Cardozo's jury had agreed to abide by a majority vote. During post-trial motions in the Robert Smalls case (Melton was also Smalls' attorney), Melton requested that the jury be polled, citing as grounds that he had learned that the Cardozo jury should have been polled because of their majority-vote agreement. By failing to move to have the jury polled, however, Melton forfeited Cardozo's right to appeal on the ground that the jury had decided the case by a majority vote. ${ }^{11}$

Cardozo's motion for a new trial was denied on 16 November 1877, and his motion for an arrest of the judgment was denied on the following day. On 26 November, in a scathing speech, Judge Townsend condemned Cardozo as a member of that class whose 'watchwords... were plunder and oppression, and its cardinal principles - aggrandizement of self to the utter exclusion of a single consideration of the public good.' He then sentenced him to two years in jail and a $\$ 4,000$ fine with an additional year if the fine was not paid. ${ }^{72}$

Many historians assume that Cardozo was pardoned by Governor Wade Hampton shortly after the trial based on an agreement between Hampton and President Rutherford B. Hayes whereby the federal government dropped prosecutions against Democrats for election fraud. L. Cass Carpenter, the only white of the three people convicted of corruption, did receive a quick pardon from Hampton in February 1878. But for Cardozo and Robert Smalls, the benefits of the agreement were slow in coming. ${ }^{73}$

According to Melton, Cardozo refused a pardon because he wanted a 'fair trial.' Cardozo could not make his bond of $\$ 35,000$ and spent nearly seven months in jail. Unfortunately, Cardozo's desire for a fair trial played into the hands of the Democrats, since Hampton and Hayes were still negotiating. In March 1878 Hampton had written President Hayes, pointing out that he had pardoned Carpenter but had taken no action on Cardozo because the appeal was still pending. Hampton further reiterated that ' $[t]$ here are but three men from this State now in the Albany Penty on the $\mathrm{Ku} \mathrm{Klux}$ charges I have already asked you to pardon... Let me renew this request, and ask you to issue a Proclamation of pardon to those charged with complicity in the Ku Klux cases. Several of these men are anxious to return and I feel sure that you could do nothing which would be more grateful to our people.' In April 1878, Cardozo's bond was reduced to $\$ 8,000$, and he was released. ${ }^{74}$

Hampton was demanding in his negotiations. In May, either in appreciation or as a quid pro quo for the reduced bail, Cardozo wrote President Hayes, giving credit to Hampton for the reduction in his bail and 
urging the President to grant Hampton's request for a pardon for the three Klansmen. One has to believe that Cardozo was not expressing his true feelings, which were probably more in line with the letter he wrote to Senator Charles Sumner in 1872. In that letter, read to the United States Senate, Cardozo opposed amnesty for Confederate veterans, citing Klan violence in South Carolina. Cardozo said the black citizens of the state surely did not support amnesty 'when they see their leading men assassinated, their wives and children brutally whipped in the dead of night by $\mathrm{Ku}$ Klux, a band of the most cruel conspirators that ever disgraced any civilized society.' By June 1878 Hampton informed a relative of one of the Klansmen that President Hayes had assured him his brother could return to the state. That Klansman was Dr. Rufus Bratton, who had fled to Canada to avoid charges of conspiracy to murder a black man in 1871 . By July 1878 Hayes had pardoned all the Klansmen being prosecuted in the federal courts of South Carolina, and Cardozo still waited for his 'fair trial. ${ }^{75}$

\section{The Appeal and Its Aftermath}

Francis Cardozo's appeal to the South Carolina Supreme Court was heard at the April 1878 term of the court, but the decision was not rendered until 29 November. Samuel Melton continued to represent Cardozo on appeal and C.R. Miles argued for the state. Melton had appealed on numerous grounds, but only one ground found support from any of the three supreme court justices. That ground was from the opening moments of the trial, when after the state had stricken the first two black jurors presented, the judge refused to allow Melton to strike the white jurors called as replacements. Melton's position, obviously, was that his peremptory challenges had been improperly denied. The court was divided. One opinion was by Chief Justice Amiel J. Willard, a Republican who had nonetheless sided with the Democrats in all the 1876 election cases whereby Republicans were ousted from office and Hampton's administration installed. Judge Willard agreed with Melton's argument and opined that Cardozo's challenge to the two jurors had been improperly denied. However, the two Democratic members of the court did not agree with Willard's position on the jury selection. Justices Henry McIver and A.C. Haskell concluded that 'the ruling of the Circuit judge, in refusing to allow the defendant to challenge peremptorily the two jurors, Wiley and Fields, was correct, whatever differences of opinion may exist as to the reason given for such ruling.' McIver was a Democrat, a delegate to the secession convention of 1860 , a Confederate veteran, and the first supreme court judge elected by the Democrats after the withdrawal of the federal troops. He was a Red Shirt and had campaigned for Hampton in 
1876 by participating in the Democratic strategy of insisting on the right to speak at or disrupting Republican rallies. A.C. Haskell had also been a Red Shirt and led an armed group called Haskell's Raiders that harassed Republican rallies. One friendly biographer described Haskell as 'a terror to the Radicals in those dark days.' Haskell was an avowed 'straightout' Democrat and a white supremacist. ${ }^{76}$

Melton had been convinced of the merits of his case and had predicted in a letter to President Hayes that despite the political makeup of the court, he had no doubt that Cardozo 'will have a new trial. ${ }^{177}$ But he was wrong, because the two Hampton cohorts would not support Cardozo's right to a 'fair trial.'

Cardozo's appeal was denied by the state supreme court on 28 November 1878. Employed by the federal government in Washington, D.C, but under threat of arrest, he returned to South Carolina and was jailed on 24 March 1879. In February, his brother, the Reverend Henry Cardozo, had obtained petitions supporting a pardon signed by many prominent citizens and by ten of the 12 jurors from the trial. In a letter to Governor William D. Simpson which accompanied the petitions, Henry Cardozo urged consideration of the fact that his brother's wife was an invalid with five living children under the age of 12 . Governor Simpson did issue pardons for Cardozo and Robert Smalls on 23 April 1879, but only after the United States Attorney for South Carolina had nol prossed all of the pending election fraud cases against white Democrats in South Carolina and after Cardozo had spent a total of nine months in jail. ${ }^{78}$

Freed from jail, Cardozo returned to Washington, D.C. According to a letter by Judge Samuel Shellabarger to John Sherman, Cardozo had 'lost every dollar of an estate of about $\$ 10,000$ and is now living here, poor and with a family.' This letter, and what other evidence can be found of Cardozo's financial dealings, indicate that Cardozo had not acquired great wealth during his tenure in public office and that, in fact, he was close to destitution after being released from jail. During the trial South Carolina newspapers had reported that either Cardozo's wife or another member of the family claimed to have money in England. But while Cardozo lived in South Carolina, his land holdings never exceeded $\$ 7,000$ in value at any one time, and the majority of his land transactions took place before he was treasurer. While he was treasurer, the Cardozos made only two real estate purchases for $\$ 2,250$. Considering that Cardozo's annual salary as a state official was between $\$ 2,500$ and $\$ 3,000$ from 1868 to 1877 , these purchases do not seem extravagant. In any case, the Cardozos had lost all of their property except one piece by early 1878 . On the eve of the trial, they sold their home and land in Columbia for $\$ 4,500$, and lost their property in Washington D.C. to foreclosure a few months after he was 
jailed. They apparently rented homes in Washington, D.C. until they were able to finance the purchase of a home in $1886 .{ }^{79}$

Cardozo had moved his family to Washington, D.C. before the trial. After his release from jail on an appeal bond, he also had gone to the capital and sought employment with the Hayes administration. A family story is that some Republican Party leaders presented Cardozo to President Hayes to seek employment and that when Hayes offered Cardozo a job cleaning spittoons, Cardozo turned on his heels and walked out on the President. However, the story seems apocryphal, as Hayes wrote Secretary of Treasury John Sherman on 9 August 1877 urging him to offer employment to Cardozo if practicable. Sherman did employ Cardozo in the U.S. Treasury where he worked for six years. After the move to Washington, Cardozo did not pursue an active role in politics, other than to use his political connections in pursuit of advancement in government service. Prior to his conviction, Cardozo had been a leading national figure in Republican and African American politics, but when national conventions of African Americans were held in 1879 and 1883, Cardozo did not participate. And it is also clear that he had no further use for the South. After a speaker at a local literary group, the Bethel Literary Society, cited the growing population of African Americans in the South as a harbinger of political future for them in the region, Cardozo described the idea as a chimera. Ultimately he grew so embittered by the status of his people in the United States that he advocated emigration to Haiti or Liberia. ${ }^{80}$

When Democrat Grover Cleveland was elected to the presidency in 1884, Cardozo lost his job with the treasury department. He decided to return to the teaching profession. Cardozo had taught at Howard University in 1871 before he became treasurer of South Carolina. Of this opportunity to teach, he wrote, 'I did this under a profound conviction that I can be of more service in the great work of reconstruction in the South by occupying such a position, where I can prepare the rising generation, of my own race especially, for the honourable discharge of the important duties resting upon them as American Citizens.' In 1884, Cardozo was to return to the classroom for good. Some praised him as an educator. For example, The Colored American newspaper said the high school he served as principal 'seemed to take on a new life, and in a few years it had grown beyond the limits of the building.' But some critics, such as newspaperman Calvin Chase of the Washington Bee, never let Cardozo or the people of the District of Columbia forget his conviction. In fact, Chase campaigned for years to have Cardozo fired by the school board. Cardozo taught in the public schools of Washington, D.C. until his resignation for health reasons on 10 June 1903. He died on 22 July 1903. Francis L. Cardozo High School in Washington, D.C. was named in his honor in $1906 .{ }^{81}$ 


\section{Conclusion}

While larger questions were posited at the beginning of this essay, it would be disingenuous not to ask the question of whether Cardozo was guilty of the charges made against him. The answer to that question is most likely 'No.' Perhaps one should be reluctant to draw such a conclusion without a full recantation by one of the state's witnesses whose demeanor there is no opportunity to observe, but weighing all the evidence with these limitations, a legal scholar can easily conclude that the state did not prove its case beyond a reasonable doubt. Cardozo was convicted by the testimony of witnesses who had motives of revenge and self-preservation. The evidence of these supposed co-conspirators was conflicting and, in large measure, impossible to believe. Official records proved that the state's case was simply not based on the facts. Moreover, the witnesses for the state were caught in contradictions and lies. Finally, the state or its witnesses manufactured and created evidence. Therefore there is overwhelming doubt as to Cardozo's guilt.

Cardozo was prosecuted by lawyers with conflicts of interest and with political motives. The judge demonstrated bias again and again. The process for jury selection had been manipulated by the Democrats after their ascension to power. The chance that black jurors were intimidated by the jailers and the white jurors was enhanced by the sequestration of the jury. Historians have reported that black jurors had been easily controlled by white jurors even during Reconstruction, and the chance of such intimidation after the election of 1876 was much greater. In fact, after his conviction, L. Cass Carpenter claimed that he had affidavits from two jurors who swore they voted to convict him because they feared for their lives. In addition, the black voters in Richland County were not monolithically Republican. A majority verdict was contrary to state law, but the Redeemers needed only one black juror to vote to convict Cardozo by a simple majority. Instead of legitimacy and legality, the trial demonstrates a perversion of justice. ${ }^{82}$

So why was Cardozo convicted? To answer this requires looking at the implications of the conviction. To the Redeemers who had cried corruption, Cardozo was the ideal target. He was considered the most honest man of his party. He had been the treasurer for six years, and in large measure the leader of his party since 1868 . Moreover, he was black. The press ensured that his trial would be a political show. The arguments at the trial were permeated by political and racial overtones. The Redeemers convicted Cardozo, but to do so they had to work hand in hand with admittedly corrupt Republicans. Wade Hampton and the Redeemers could not claim they cleaned up state government, since they 
recovered little or no financial recompense for the state and obtained only three convictions. Cardozo was the only statewide office holder they convicted. They never obtained the conviction of a major scalawag or carpetbagger, much less any Democrats implicated in corruption. The Redeemers needed Cardozo's conviction. They had intimidated most Republican politicians into resigning, and it would have served no purpose to prosecute minor political figures such as the legislators who may have taken small bribes. In fact, the jailing of hundreds would probably have created an enormous backlash. Prosecuting prominent scalawags and carpetbaggers would have meant trouble for many leading Democrats who had participated in various financial schemes with these Republicans during Reconstruction. In addition, many of these carpetbaggers had fled, so there was little reason to make the effort to obtain their convictions. It was simply 'good riddance.'

Even if Cardozo had not been targeted, his insistence on being tried played right into the hands of the Redeemers by providing them with a valuable political pawn in their negotiations with President Hayes. The Redeemers had to match the moves of the Hayes administration. First, it was three state prosecutions in response to the three federal prosecutions. Then the stakes grew even larger. As a result, innumerable Klansmen and other whites who had committed violence and election fraud were freed from prosecution and even prison in exchange for Cardozo and Smalls. So the ideal of justice did not prevail in the Cardozo trial. Here was the paradox of the Southern judicial system. Christopher Waldrep has observed that 'Blacks' embrace of objective justice may have made it easier for whites to reject that paragon. ${ }^{83}$ As the opening quotation of this article demonstrates, Cardozo's own idyllic view of the law certainly fits Waldrep's observation. The cynical and racist post-Reconstruction justice that convicted Francis Cardozo soon led to Jim Crow, and its roots spread across America.

How much did racism pervert the outcome? Cardozo was a powerful African American leader. He was the only black man elected to statewide office in every single election during Reconstruction in South Carolina. Even in the election of 1876 , Cardozo had not lost at the polls. Such a man had to be defeated, and convicting him was the sure way to eliminate him as a threat to white political domination. Moreover, Cardozo had been the leading black reformer of the Republican Party, and to convict him would prove every black elected Reconstruction official evil. Cardozo was also considered the brightest man of his race in South Carolina. He had been educated at finer institutions than virtually anyone else in the state. Beating down such a man was essential to those trying to prove the innate inferiority of the black race. Convicting Cardozo demonstrated to their 
satisfaction that a well-educated, successful, proud, and even elitist black man could be corrupt and defeated.

The Redeemers accomplished their goals. On the most personal of levels, they victimized Cardozo. His conviction broke him in wealth and spirit. But worse, the Redeemers made their case to the South, the nation, and to history for many years that the Republicans and the African Americans were corrupt and inferior. It is hoped that with this in-depth examination of the Cardozo prosecution, legal scholars and historians will more carefully focus on the actual charges of Reconstruction corruption and the resulting trials. Such a focus can answer the question of whether such perversions as Cardozo's conviction were the norm and if so, whether they helped perpetuate the story of Reconstruction corruption while blotting out its accomplishments.

\section{ACKNOWLEDGMENTS}

This article is based on a paper presented at the annual meeting of the American Society for Legal History meeting in 2000 at Princeton. Another version of this article, entitled 'PostReconstruction Justice,' will appear in the South Carolina Law Review. I want to express appreciation to my South Carolina colleagues Vance Cowden, Bill McAninch, and Herb Johnson, and Michael Mounter and to Michael Curtis of Wake Forest Law School, to John Oldfield of Southampton University, Lou Falkner Williams of Kansas State, Christopher Waldrep of California State University, and Joel Williamson of the University of North Carolina for their comments. Research assistants Justin Werner, Josh Williams, and Steve Bates are owed much. A thank you is owed to my wife, Anne, for both her support and editorial work. Of course, all mistakes are without question mine.

\section{NOTES}

1. Proceedings of the Constitutional Convention of South Carolina 1868 (New York: Arno Press and New York Times, 1968), p.354. This quotation is from the debate concerning the wording of the Bill of Rights in the South Carolina Constitution of 1868.

2. John Farley, 'Francis L. Cardozo,' B.A. diss., Princeton University, 1949, pp.128-37; Edward F. Sweat, 'Francis L. Cardoza - Profile of Integrity in Reconstruction Politics,' Journal of Negro History 46 (July 1961) pp.217, 231; Joel Williamson, After Slavery: The Negro in South Carolina During Reconstruction, 1861-1877 (Chapel Hill: University of North Carolina Press, 1965) pp.388, 415-16.

3. The term 'Redeemer' refers to those Democrats who claimed to have redeemed the South in the 1870s from the control of African Americans and Republicans. See Joel Williamson, Crucible of Race (New York: Oxford University Press, 1984) p.51, 82. See also C. Vann Woodward, Origins of the New South: 1877-1913 (Baton Rouge: Louisiana State University Press, 1951), Chapter 1. See Reports and Resolutions of the General Assembly of the State of South Carolina at the Regular Session, 1877-78 (Columbia, 1878), which exceeds 1700 pages in length.

4. See Farley, 'Francis L. Cardozo,' p.1; Eric Foner, Freedom's Laumakers (New York: Oxford University Press, 1993), p.39; Thomas Dixon, Jr., The Clansmen (New York: Doubleday, Page \& Co. 1905); The State (Columbia, S.C.), 18 Mar. 1906; Chester L. Quarles, The Ku Klux Klan and Related American Racialist and Antisemitic Organizations (Jefferson, N.C.: McFarland \& Co., 1999) p.53; Glenn Feldman, Politics, Society, and the Klan in Alabama (Tuscaloosa: 
University of Alabama Press, 1999) pp.12-13; Robert Lang (ed.), The Birth of a Nation: D.W. Griffith Director (New Brunswick, N.J.: Rutgers University Press, 1994), p.149; Hilary A. Herbert (ed.), Why the Solid South (Baltimore: R.H. Woodward \& Co., 1890), pp.88-119. Frederic A. Bancroft, A Sketch of the Negro in Politics Especially in South Carolina and Mississippi (New York: AMS 1976 [1885]), pp.22-33; and John W. Burgess, Reconstruction and the Constitution 1866-1876 (New York: Charles Scribners' Sons, 1902), pp.261-64; the chief literary works of this popular racist culture were written by Thomas Dixon. Aside from The Clansman, see The Leopard's Spots (New York: Doubleday, 1902). Joel Williamson says Dixon reached millions of Americans with his racist stories. See Crucible of Race, p.141; Martha Hodes, White Women, Black Men New Haven: Yale University Press, 1997) pp.151-210. While it is true that Hodes found cases during Reconstruction in which black men were lynched or mutilated by the Klan because they were Republicans, often the Klan alleged sexual impropriety as an excuse for the attack. Even early historians such as Frederic A. Bancroft opined that blacks were assaulted by the Klan during Reconstruction solely for political reasons. See Sketch of the Negro in Politics, p.55. The other attempted rape scene of Birth of a Nation depicted a black militia member as the culprit, a scene dubbed by one scholar as baseless. See Bernard A. Weisberger, 'The Dark and Bloody Ground of Reconstruction Historiography,' Joumal of Southem History, 25 (Nov. 1959), pp.432-33; Peter Noble, 'The Negro in the Birth of a Nation,' in Fred Silva (ed.), Focus on Birth of a Nation (Englewood Cliff, N.J.: Prentice-Hall, 1971), pp.125-32.

5. James S. Pike, The Prostate State (New York: Appleton \& Co., 1874); John S. Reynolds, Reconstruction in South Carolina (New York: Negro Universities Press, 1969 [1905]), pp.86-87; Eric Foner, Reconstruction (New York: Harper \& Row, 1988). For example, see Foner's discussion of corruption in the 'Age of Capital,' in Reconstruction, pp.465-69, and in South Carolina in particular, pp.386-90, 570-75.

6. Eslanda Robeson Papers, Moorland-Spingarn Collection, Family Papers Box 1, Howard University; Papers of Francis Lewis Cardozo, Manuscript Division, Library of Congress (hereafter FLCP); Joe Richardson, 'Francis L. Cardozo: Black Educator during Reconstruction,' Joumal of Negro Education 48 (Winter 1979) p.48; the Secretary of the Glasgow Principal to William Cardoza, 10 Nov. 1930 (FLCP). Cardozo attended the United Presbyterian Hall in the 1861 session. Records of New College, e-mail to author, Irene Ferguson, assistant to University of Edinburgh archivist, 12 Apr. 2001; Edmund Drago, Initiative, Patemalism \& Race Relations: Charleston's Avery Normal Institute (Athens: University of Georgia Press, 1990) pp.46, 48.

7. James Lowell Underwood, 'African American Founding Fathers: The Making of the South Carolina Constitution of 1868, in James Lowell Underwood and W. Lewis Burke (eds.), At Freedom's Door (Columbia: University of South Carolina Press, 2000), pp.2, 3, 8, 9, 14; Foner, Freedom's Lawmakers, p.39. Reynolds, Reconstruction in South Carolina, pp.86-87, who noted that Cardozo was the only 'colored' on the Republican ticket. This ticket was elected in the elections held on 13,14, and 15 Apr. in 1868. Francis Butler Simkins and Robert Hilliard Woody, South Carolina During Reconstruction (Chapel Hill: University of North Carolina Press, 1932) p.114, and A.A. Taylor, The Negro in South Carolina During Reconstruction (New York: Russell \& Russell, 1969 [1924]) p.224; Richard Zuczek, State of Rebellion (Columbia: University of South Carolina Press, 1996) p.50. Cardozo achieved this 'first' by only two days, as Oscar J. Dunn was elected lieutenant governor of Louisiana in that state's elections held on 16 and 17 Apr. 1868. See Joe Gray Taylor, Louisiana Reconstructed (Baton Rouge: Louisiana State University Press, 1974) p.50; Simkins and Woody, South Carolina During Reconstruction, p.448; Carol K.R. Bleser, The Promised Land: The History of the South Carolina Land Commission (Columbia: University of South Carolina Press, 1969) p.89; Foner, Reconstruction, p.375; Robert Selph Henry, The Story of Reconstruction (Indianapolis and New York: Bobbs-Merrill, 1938), p.445.

8. Simkins and Woody, South Carolina During Reconstruction, p.182; Williamson, After Slavery p.399; Peggy Lamson, The Glorious Failure (New York: W.W. Norton, 1973) p.52; W.E.B. Dubois, Black Reconstruction in America (New York: Harcourt Brace \& Co. 1935) pp.413-14; David Duncan Wallace, The History of South Carolina 4 vols. (New York: American Historical 
Society, 1934) vol.3, pp.292-93; Daily Union Herald (Columbia, S.C.), 21 Feb. 1875 (reprinting an editorial from the Democratic Charleston News $\&$ Courier); Daily Union Herald, 5 Feb. 1875; Victor Ullman, Martin R. Delany: The Beginning of Black Nationalism (Boston: Beacon Press, 1971), p.435; Walter Allen, Governor Chamberlain's Administration in South Carolina (New York: G.P. Putnam's Sons, 1888), p.8.

9. The Press and Banner (Abbeville, S.C.), 3 Mar.1875; The Yorkville Enquirer (S.C.), 4 Mar. 1875. At the time Cardozo took office the state bonded indebtedness exceeded $\$ 21,000,000$, and he began an effort at consolidating this debt that proved quite successful, reducing the debt to about $\$ 7,000,000$. A legislative committee accused Cardozo of consolidating $\$ 978,500$ in bonds that they claimed 'should not have been funded.' The issue of which bonds should or should not have been consolidated was not resolved for years. A special court of claims was established in 1879 to hear the claims of the various bond holders, and this court declared that most of the consolidation bonds were issued unconstitutionally, but the validity of the bonds was still being contested as late as 1881. Simkins and Woody, South Carolina During Reconstruction, pp.168, 172-75; The Daily Union Herald (Columbia, S.C.), 3 Mar. 1875; Allen, Governor Chamberlain's Administration in South Carolina, pp.86, 269; The New York Times, 16 Mar. 1875.

10. Lamson, The Glorious Failure, p.30; Simkins and Woody, South Carolina During Reconstruction, p.77; Address Before the Grand Council of the Union Leagues at the Annual Meeting held July 27, 1870 by Hon. F.L. Cardozo, President (1870), South Caroliniana Library, University of South Carolina; Allen, Govemor Chamberlain's Administration in South Carolina, pp.47, 81-84, 360, 397, 482; W. Lewis Burke, Jr., 'The Radical Law School: Its African American Graduates 1873-1877,' in Underwood and Burke, At Freedom's Door, p.101; Roll of Attomeys, South Carolina Supreme Court (1876).

11. See Simkins and Woody, South Carolina During Reconstruction, p.480; Walter Edgar, South Carolina: A History (Columbia: University of South Carolina Press, 1998) pp.402-404; Lamson, The Glorious Failure, pp.252-54; Richard Gergel and Belinda Gergel, 'To Vindicate the Cause of the Downtrodden' in Underwood and Burke, At Freedom's Door, pp.36, 51-56; The Charleston News $\&$ Courier (S.C.), 27, 28 Nov. 1876; F.L. Cardozo to Wade Hampton, 16 Apr. 1877, in 'Scrapbook: $1876-1885$ ' in the Leroy Franklin Youmans Papers, South Caroliniana Library (hereafter SCL); see the petition in the record in The State ex rel. William H. Wallace, et al, vs. the Carolina National Bank, et al., in the Daniel A.P. Murray Collection, Libraty of Congress; Foner, Reconstruction, pp.575-76, 582; Wade Hampton to F.L. Cardozo, 14 Apr. 1877, Governor Wade Hampton Papers, South Carolina Department of Archives and History (hereafter SCDAH); F.L. Cardozo to Wade Hampton, 16 Apr. 1877 in 'Scrapbook: 1876-1885,' LeRoy Franklin Youmans Papers, SCL; 'Report of the Attorney General to the General Assembly' (31 Oct. 1877) in Reports and Resolutions of the General Assembly of the State of South Carolina (Columbia: Calvo \& Patton, 1877) p.318; Allen, Govemor Chamberlain's Administration in South Carolina, pp,482-83; The Press (Philadelphia, Pa), 2 May 1877.

12. 'Concurrent Resolution to Appoint Joint Committee of Investigation,' 8 June 1877, in Joumal of the Senate of the State of South Carolina, Extra Session, App. 9 (Columbia: Republican Printing Company, State Printers, 1877); correspondence of Wade Hampton and Rutherford B. Hayes in Hampton M. Jarrell, Wade Hampton and the Negro (Columbia: University of South Carolina Press, 1949) pp.175-76.

13. The Register (Columbia, S.C.), 29 July 1877; The Charleston News $\mathcal{E}$ Courier (S.C.), 23 July 1877; see the Cardozo letter to The Press (Philadelphia), 1 Aug.1877; Edgar, South Carolina: A History, p.410; James Conner to W.D. Simpson, 24 Aug.1877, quoted in Williamson, After Slavery, p.415; The Intelligencer (Anderson, S.C.), 18 Aug. 1877.

14. 'Report of the Attorney General to the General Assembly of South Carolina for the Fiscal Year Ending October 31, 1877,' in Reports and Resolutions of the General Assembly of the state of South Carolina at the Regular Session, 1877-78 (Columbia, 1878), pp.321-27; Beaufort Tribune $\mathcal{E}$ Port Royal Commercial, 12 Sept. 1877 (in Aiken County, Henry Sparnick, the probate judge and publisher of an Aiken newspaper, was charged and found guilty of embezzling $\$ 2,700$ ); The Charleston News $\mathcal{E}$ Courier (S.C.), 10 Oct. 1877 (the county commissioners of Williamsburg County were tried for misconduct, but the proceeding ended 
in a mistrial); The Register, (Columbia, S.C.) 6 Apr. 1878 (the Republican mayor of Columbia was convicted of mistreating a drunk, but pardoned); The Charleston News $\&$ Courier (S.C.), $11 \mathrm{Feb} .1879$ (Judge Samuel Lee of Sumter who was charged with 'official misconduct' for closing his office); William E. Earle to D.T. Corbin, 9 Mar.1878, Rutherford B. Hayes Presidential Library (hereafter RBHL); Bancroft, Sketch of the Negro in Politics, p.74; The Charleston Journal of Commerce (S.C.), 6 Oct. 1877.

15. Edward A. Miller, Jr., Gullah Statesman (Columbia: University of South Carolina Press, 1995); George Brown Tindall, South Carolina Negroes 1877-1900 (Columbia: University of South Carolina Press, 1952), pp.133-35; Biographical Directory of the American Congress, 1774-1996 (Alexandria, Va.: CQ Staff Directories, Inc., 1996), p.784; The Abbeville Medium (S.C.), 5 Sept. 1877; The Charleston News $\mathcal{E}$ Courier (S.C.), 15 Nov. 1877; Testimony Taken by the Select Committee on the Recent Election in South Carolina before the U.S. House, 44th Cong., 2d sess., pp. 459-60, and South Carolina in 1876 (testimony taken before the U.S. Senate, 19 Dec. 1876), pp.224-26.

16. 'Report of the Special Joint Committee,' in Reports and Resolutions of the General Assembly of the State of South Carolina at the Regular Session, 1874, pp.780-82; Communication from the State Treasurer in Reply to Report of the General Assembly of the State of South Carolina at the Regular Session, 1874 (Columbia, 1874), pp.713-19; The Anderson Intelligencer (S.C.), 23 Aug. 1877; 'Report of the Treasurer of the State of South Carolina for the fiscal year ending October 31, 1875,' in Reports and Resolutions of the General Assembly of the State of South Carolina at the Regular Session, 1875-76 (Columbia, 1876), p.4; 'Report of the Attorney General to the General Assembly of South Carolina for the Fiscal Year Ending October 31, 1877,' in Reports and Resolutions of the General Assembly of the State of South Carolina at the Regular Session, 1877-78 (Columbia: Calvo \& Patton, State Printers 1878), pp.321-23; Taylor, Louisiana Reconstructed, pp.208, 212; Isabell R. Vandervelde, Biography of Samuel Jones Lee (Aiken, S.C.: Art Studio Press, 1997) pp.1-2; Taylor, Louisiana Reconstructed, p.271; The Marion Star (S.C.), 28 Nov. 1877.

17. The Charleston News $\&$ Courier (S.C.), 5, 6 Oct., 2 Nov. 1877; The Abbeville Medium (S.C.), 10, 17 Oct. 1877; The Columbia Register (S.C.), 31 Oct. 1877; The New York Tribune, 2 Nov. 1877; The New York Times, 2 Nov. 1877; T he National Republican (Washington, D.C.), 5 Nov. 1877; The Chicago Tribune, 4 Nov. 1877; The Atlanta Constitution, 7 Nov. 1877; The Daily Picayune (New Orleans, LA), 3 Nov. 1877; The Charleston Joumal of Commerce (S.C.), 5 Oct. 1877.

18. Simkins \& Woody, South Carolina During Reconstruction, p.22; U.R. Brooks, South Carolina Bench and Bar (Columbia: The State, 1908), pp.187-90; Cyclopedia of Eminent Men and Representative Men of the Carolinas of the Nineteenth Century (Madison, Wis.: Brant and Fuller, 1892), p.98; S.W. Melton to Rutherford B. Hayes, 8 Apr. 1878, RBHL; William Lewis Burke, 'A History of the Opening Statement from Barristers to Corporate Lawyers: A Case Study of South Carolina,' American Joumal of Legal History 37 (Jan. 1993) pp. 41-42; Zuczek, State of Rebellion, p.166; Lamson, The Glorious Failure, pp.139-40; William E. Earle to D.T. Corbin, 9 Mar. 1878, RBHL.

19. The Columbia Register (S.C.), 2 Nov. 1877; J.C. Hemphill, Men of Mark in South Carolina, IV (Washington, D.C.: Men of Mark Publishing Co., 1909), pp.424-25; William E. Earle to D.T. Corbin, 9 Mar. 1878, RBHL. Cyclopedia of Eminent and Representative Men of the Carolinas in the Nineteenth Century (Madison, Wis.: Brant \& Fuller, 1892), pp.661-63; Roll of Attomeys, Supreme Court of South Carolina; The Columbia Register (S.C.), 2 Nov. 1877.

20. Conner Family Papers; Simkins \& Woody, South Carolina During Reconstruction, p.110; Zuczek, State of Rebellion, p.49; David Hoffman, A Course of Legal Study (New York: Arno Press, 1972 [1836]), p.753.

21. 'The Letter Press Book, South Carolina Attorney General,' Conner Family Papers; U.R. Brooks, South Carolina Bench and Bar (Columbia, S.C.: The State Company, 1908), p.187.

22. Yates Snowden (ed.), History of South Carolina (Chicago and New York: The Lewis Publishing Co., 1920), p.155; The Chester Reporter, 18 Feb. 1875; N. Louise Bailey (ed.), Biographical Directory of the South Carolina Senate 3 vols. (Columbia: University of South Carolina Press 1986) vol. 2, pp.941, 1008, 1392; Marion Star (S.C.), 10, 27 Mar. 1875. 
23. The Charleston News \& Courier (S.C.), 2 Nov. 1877; The Columbia Register (S.C.), 7 Nov. 1877.

24. The Columbia Register (S.C.), 2 Nov. 1877; The State v. Gleaves, Lee, Woodruff, Jones, Cardozo, 'Handwritten Trial Notes' in Charles Richardson Miles Papers (SCL) [hereinafter 'Trial Notes']; The Charleston News \& Courier (S.C.), 2 Nov, 1877.

25. The Bamwell People (S.C.), 17 Nov. 1877; The New York Times, 2 Nov. 1877, The Yorkville Enquirer (S.C.), 8 Nov. 1877, and The News 8 Herald (Winnsboro, S.C.), 6 Nov. 1877; The Pickens Sentinel (S.C.), 15 Nov. 1877; See, for example, The New York Times, 6 Nov. 1877 ('a mistrial is expected by the public, from the composition of the jury.'); The New York Tribune, 7 Nov. 1877 (An agreement is not expected, it being thought that the jury is equally divided.'); The Charleston News $\mathscr{E}$ Courier (S.C.), 7 Nov. 1877 ( Its headline read, 'The case given to the jury and the jury unable to agree')

26. Cardozo Jury Data:

\begin{tabular}{llll}
\hline Name & Race & Literate & Occupation (from city dir. or census) \\
\hline George Washington & black & no & farm hand/carpenter \\
Henry Williams & black & possibly & turpentine hand/farmer/white washer* \\
Francis Hammond & white & no & farmer \\
Joseph Walker & black & no & laborer/Asylum keeper \\
W.P. Jacobs & white & possibly & turpentine farmer \\
Vince Thompson & mu. & no & farmer \\
Edward Tucker & black & no & farm laborer/farmer \\
Simon Jenkins & black & yes & former county commissioner \\
Wm. T. Martin & white & yes/no & compositor/farmer \\
Samuel W. Rowan & white & yes & clerk of market/bookkeeper \\
John S. Wiley & white & yes & clothier Iforeman of the jury] \\
John Field & white & no & farm laborer/farmer \\
\hline
\end{tabular}

Source: The Columbia Register (S.C.), 2 Nov. 1877. Also see 1870 Census (U.S. Bureau of Census Population Schedules (S.C.), M593, Reel 1507); Beasley \& Emerson, Columbia Directory (1875-76); and 'Report of the Attorney General to the General Assembly of South Carolina,' in Reports and Resolutions (1878), p.328. (Henry Williams was a very common name, with six listed in the city directory for 1879-80. See Columbia Directory. All six were listed as 'colored.' The 1870 census lists five. See 1870 Census. All of them over the age of 20 were illiterate, and all were black, except one who was listed as 'mulatto.')

27. The Columbia Register (S.C.), 2 Nov. 1877; The Winnsboro News and Herald (S.C.), 6 Nov. 1877; The New York Times, 4 Nov. 1877, and The Yorkville Enquirer, (S.C.), 8 Nov. 1877; The Charleston News $\&$ Courier (S.C.), 10 Oct. 1877.

28. The Columbia Register (S.C.), 2 Nov. 1877.

29. 'Trial Notes,' p.1; The Marion Star (S.C.), 1 Aug. 1877; Woodruff Diary, 14 Aug. 1874; Report of the Joint Investigating Committee on Public Frauds, in Reports and Resolutions (1878). pp.1563-64; John Oldfield, 'The African American Bar in South Carolina,' in Underwood and Burke, At Freedom's Door, pp.122-23; The Charleston News 8 Courier (S.C.), 8 June 1878; J.R. Oldfield, 'A High and Honorable Calling: Black Lawyers in South Carolina, 1868-1915,' Joumal of American Studies 23 (Dec. 1989), pp.395, 400-402; Brooks, South Carolina Bench and Bar, pp.187-90; South Carolina Reports, vols.14-43 (1880-94).

30. 'Trial Notes,' p.2; The Charleston News 8 Courier (S.C.), 2 Nov. 1877; 'The State, Respondent, vs. F.L. Cardozo, Appellant. Points and Authorities submitted on behalf of the Appellant, by Mr. Sam'l Melton,' pp.3-4 (citing Evid., Folio 25) in Frederick Douglass Papers Library of Congress [hereinafter 'Points and Authorities'].

31. The Columbia Register (S.C.), 2 Nov. 1877; 'Trial Notes,' pp.2-3; The Charleston News \& Courier (S.C.), 2 Nov. 1877.

32. The Charleston News 8 Courier (S.C.), 2 Nov. 1877; 'Trial Notes,' pp.3-4.

33. The Fairfield Herald (S.C.), 10 Mar. 1875, The Columbia Register (S.C.), 2 Nov. 1877; The Charleston News 8 Courier (S.C.), 2 Nov. 1877; 'Trial Notes,' p.5. 
34. E. Culpepper Clark, Francis Warrington Dawson and the Politics of Restoration (University: University of Alabama Press, 1980), p.72; The Charleston News $\mathscr{E}$ Courier (S.C.), 2 Nov. 1877; The People (Barnwell, S.C.), 6 Dec. 1877; Woodruff Diary, 10 Mar. 1876; The Charleston News 8 Courier (S.C.), 26, 31 July 1877; 'Report of the Joint Investigating Committee,' in Reports and Resolutions (1878), pp.1034, 1041-93; Joumal Of Commerce (Charleston, S.C.) 2 Sept. 1877, reprinted in The Marion Star (S.C.), 4 Sept. 1877; James Conner to C.H. Simonton and T.Y. Simon (7 Sept. 1877), in 'Letter Press Book, South Carolina Attorney General,' Conner Family Papers; The Charleston News $\mathcal{E}$ Courier (S.C.), 5 Nov. 1877; see bond dated 1 Aug. 1877, by which Woodruff and his wife put up their home at 191 Meeting Street, Charleston, S.C. as security in the amount of $\$ 10,000$ (Charleston County, South Carolina Register of Mesne Conveyances, Book G, Folio 61). This bond was satisfied by the attorney general on 19 Nov. 1877; The Charleston News $\mathcal{E}^{\prime}$ Courier (S.C.), 1 Aug. 1877.

35. The Charleston News $\mathcal{G}$ Courier (S.C.), 2 Nov. 1877.

36. 'Trial Notes,' p.6; The Charleston News $\mathcal{E}$ Courier (S.C.), 2, 3 Nov. 1877.

37. 'Trial Notes,' p.6; The Charleston News \& Courier (S.C.), 9 Oct. 1877; 'Senate Clerk Shorthand Notes,' in Record of the General Assembly (SCDAH); examination of the shorthand by Jane Johnson and Anne Morrison (both attorneys trained in shorthand) was conducted at the author's request in September 2000 in Columbia, S.C.; 'Trial Notes,' p.6; State v. Rawls, 2 S.C.L. 331 (1 Nott \& McC. 1820); Woodruff to the chairman of the committee, 11 Sept. 1887, Joint Investigative Committee Letter File (SCDAH).

38. Portions of the translated diary dating from July 1874 to 21 Oct. 1874 and Aug. 1875 to 30 Dec. 1875 were published in R.H. Woody, 'Behind the Scenes in the Reconstruction Legislature of South Carolina: Diary of Josephus Woodruff, Joumal of Southem History 11 (Feb. and May 1936) pp.78-102, 233-59; Joint Investigative Committee Report on Public Ptinting, in Reports and Resolutions of 1877, p.1233; The Enterprise $\mathcal{E}^{2}$ Mountainer (Greenville, S.C.), 10 Feb. 1875 and The Daily Union Herald (Columbia, S.C.), 23 Feb. 1875; Woodruff Diary, 26 Aug. 1873, 11, 19, 25 Aug., 2 Sept. 1874; Williamson, After Slavery, p.388, n.67; Woodruff Diary, 2, 17 Aug., 10 Sept. 1874; Zuczek, State of Rebellion, pp.160-61.

39. The Charleston News $\mathcal{E}$ Courier (S.C.), 3 Nov. 1877; Trial Notes, pp. 6, 8; 'Points and Authorities,' p.34.

40. 'Points and Authorities,' pp.4-6.

41. The Yorkwille Enquirer (S.C.), 8 Nov. 1877; The Columbia Register (S.C.), 8 Nov. 1877.

42. The Charleston News $\mathcal{E}$ Courier (S.C.), 3 Nov. 1877; State 4. Cardozo, 5 S.C. 297, 314 (1874); Frazee v. Cardozo, 6 S.C. 315 (1875).

43. The Charleston News $\mathcal{E}$ Courier (S.C.), 3 Nov. 1877.

44. The Chatleston News $\&$ Courier (S.C.), 3 Nov. 1877; The Columbia Register (S.C.), 4 Nov. 1877; 'Trial Notes,' pp.15-16; 'Points and Authorities,' pp.6-7, 8.

45. The Charleston News \& Courier (S.C.), 3 Nov. 1877; 'Trial Notes,' pp.15-16, 19; Simkins and Woody, South Carolina During Reconstruction, pp.58-59, 62, 466.

46. 'Trial Notes,' pp.19-20, 22; Woodruff Diary, 29 Feb., 1, 8, 9 Mar. 1876; Snowden, History of South Carolina, pp. 918-19; Woodruff Diary, 8 Sept. 1874 and 8 Sept. 1875; Allen, Governor Chamberlain's Administration in South Carolina, p.145; Wallace, The History of South Carolina, vol.3, p.277; Taylor, Louisiana Reconstructed, p.217, and Snowden, History of South Carolina, p.932; The Marion Star (S.C.), 3 Oct. 1877.

47. The Columbia Register (S.C.), 3, 4 Nov. 1877; 'Report of the Treasurer of the State of South Carolina for the Fiscal Year Ending October 31, 1874,' in Reports and Resolutions (1874) p.16; Price v. Moses, 10 Rich. 454 (S.C.L. 1857).

48. The Columbia Register (S.C.), 4 Nov. 1877; Williamson, After Slavery, p.399.

49. The Columbia Register (S.C.), 4 Nov. 1877.

50. The Charleston News \& Courier (S.C.), 5 Nov. 1877; 'Trial Notes,' pp.26, 27.

51. 'Trial Notes,' pp.27, 7; The Charleston News $\mathcal{E}$ Courier (S.C.), 5 Nov. 1877; 'Joint Investigating Commitree on Public Printing,' p.1242.

52. The Charleston News \& Courier (S.C.), 5 Nov. 1877.

53. 'Trial Notes,' pp.29-30, 31; The Columbia Register(S.C.), 4 Nov. 1877; The Charleston News 8 Courier (S.C.), 5 Nov. 1877; 'Report of the Special Joint Committee to Investigate the 
Failure of the South Carolina Bank and Trust Company,' in Reports and Resolutions of the General Assembly of the state of South Caralina at the Regular Session, 1875-76 (Columbia, 1876), pp.927-37 ; The Columbia Register (S.C.), 17 Nov. 1877; 'Report of the Special Joint Committee to Investigate the Failure of the South Carolina Bank and Trust Company,' pp.927-37.

54. The Charleston News \& Courier (S.C.); 5 Nov. 1877; 'Trial Notes,' p.32; The Columbia Register (S.C.), 3 Nov. 1877; Biographical Directory, pp.314-15.

55. State v. Brisbane, 2 Bay 451, at 452 (S.C.L. 1802); 'Trial Notes,' p.32; 1868 S.C. Acts No. 46, Sec. 89; The Charleston News \& Courier(S.C.), 6 Nov. 1877, The Columbia Register (S.C.), 6 Nov. 1877; 'Points and Authorities,' pp.3-4.

56. The Charleston News $\mathcal{E}$ Courier (S.C.), 6 Nov. 1877; The Columbia Register (S.C.), 6 Nov. 1877.

57. The Charleston News 8 Courier (S.C.), 6 Nov. 1877; The Columbia Register (S.C.), 6 Nov. 1877; 'Trial Notes,' p.22.

58. The Charleston News 8 Courier (S.C.), 6 Nov. 1877; The Columbia Register (S.C.), 6 Nov. 1877.

59. The Charleston News $\mathcal{E}$ Courier (S.C.), 6 Nov. 1877; The Columbia Register (S.C.), 6 Nov. 1877.

60. The Charleston News $\&$ Courier, 6 Nov. 1877; The Columbia Register (S.C.), 6 Nov. 1877; 'Points and Authorities,' pp.4-10; State v. Bruer, 113 S.C. 178, 102 S.E. 15, at 16 (1919); State v. Ferguson, 221 S.C. 300, 70 S.E.2d 355 at 358 (1952); The Anderson Intelligencer (S.C.), 6 Dec. 1877; The Columbia Register (S.C.), 6 Nov. 1877.

61. The Columbia Register (S.C.), 6 Nov. 1877.

62. The Columbia Register (S.C.), 6 Nov. 1877; Williamson, After Slavery, p.399.

63. Willard H. Smith, Schuyler Colfax: The Changing Fortunes of a Political Idol (Indianapolis: Indiana Historical Bureau, 1952); The Charleston News $\&$ Courier, 6 Nov. 1877.

64. The Columbia Register (S.C.), 6 Nov. 1877.

65. Price v. Moses, 10 Rich. Law 454 (S.C.L. 1857).

66. The Columbia Register (S.C.), 6 Nov. 1877.

67. 'Trial Notes,' p.32; The Charleston News \& Courier (S.C.), 11 Nov. 1877; The Columbia Register, 7 Nov, 1877; S.C. Constitution. art. 4, sec. 26.

68. The Charleston News $\mathscr{E}$ Courier (S.C.), 7 Nov. 1877; 'Points and Authorities,' pp.38-39; The Columbia Register (S.C.), 7 Nov, 1877.

69. 'Trial Notes,' p.32; The Charleston News 8 Courier (S.C.), 7 Nov. 1877.

70. Weekly Union Times (S.C.), 9 Nov. 1877; 'Trial Notes,' p.32; and The Yorkville Enquirer (S.C.), 15 Nov. 1877.

71. Weekly Union Times (S.C.), 9 Nov. 1877; 'Trial Notes,' p.32; The Chester Reporter (S.C.), 17 Nov. 1877; The Yorkuille Enquirer (S.C.), 15 Nov. 1877; The State थ. Harden, 1 Bail. 3 (S.C.L. 1828). See also William S. McAninch, 'Criminal Procedure and the South Carolina Jury Act of 1831,' in Herbert A. Johnson (ed.), South Carolina Legal History (Spartanburg, S.C.: The Reprint Company, 1980) pp.186-87; The Columbia Register (S.C.), 13 Nov. 1877; Shelton v. Maybin, 4 S.C. 541 (1873); and R.W. Shand, A Manual Containing the Constitution of South Carolina and the Rules of Court (Charleston, 1882) p. 51.

72. The Columbia Register (S.C.), 13, 18, 27 Nov. 1877.

73. Taylor, Louisiana Reconstructed, p.285; Thomas Holt, Black over White (Urbana: University of Illinois Press 1977) p.210; George Brown Tindall, South Carolina Negroes 1877-1900 (Columbia: University of South Carolina Press 1952) p.19; William J. Cooper, Jr., The Conservative Regime: South Carolina, 1877-1890, (Baltimore: Johns Hopkins Press, 1968), p.32; Edgar, South Carolina: A History, p.409; The Pickens Sentinel (S.C.), 28 Feb. 1878.

74. S.W. Melton to Rutherford B. Hayes, 8 Apr. 1878, RBHL; The Charleston News $\&$ Courier (S.C.), 4 Dec. 1877; The Yorkville Enquirer (S.C.), 11 Apr. 1878; Jarrell, Wade Hampton and the Negro, p.179.

75. The Spartanburg Herald (S.C.), 3 Oct. 1877; The Yorkville Enquirer (S.C.), 11 Apr. 1878; F.L. Cardozo to Rutherford B. Hayes, 7 May 1878, RBHL; The Congressional Globe, 42th Cong., 2d. Sess. (17 Jan. 1872), p.430; Lou Falkner Williams, The Great South Carolina Ku Klux Klan 
Trials (Athens: University of Georgia Press, 1996) pp.77, 105, 171; Jarrell, Wade Hampton and the Negro, pp.181, 185.

76. State v. Cardoza [sic], 11 S.C. 195, 229, 248 (1878). (It should be noted that the incorrect spelling of Cardozo was done by the court.); 'Points and Authorities,' pp.14-17; Brooks, South Bench and Bar, pp.58-62; Gergel and Gergel, 'To Vindicate the Cause of the Downtrodden,' pp.53-54, 62-63; Reynolds, Reconstruction in South Carolina, p.460; Alfred B. Williams, Hampton and His Red Shirts (Charleston: Walker, Evans \& Cogswell, 1935) pp.188, 312; Brooks, South Carolina Bench and Bar, p.71; Zuczek, State of Rebellion, p.161.

77. S.W. Melton letter to Rutherford B. Hayes, 22 May 1878, RBHL.

78. Farley, 'Francis L. Cardozo,' pp.141-42; The Keowee Courier (Walhalla, S.C.), 5 Dec. 1878; The Yorkville Enquirer (S.C.), 27 Mar. 1879; Governor W.D. Simpson Papers, Petitions for Pardons (SCDAH); Sheriff J.E. Dent to Wade H. Manning, secretary to Governor Simpson, 23 Apr. 1879 (SCDAH); telegram from L.C. Northrup to United States Attorney General Devens 22 Apr. 1879, Correspondence of the U.S. Attorney for South Carolina, National Archives.

79. Samuel Shellabarger to John Sherman, 24 Nov. 1878, quoted in Farley, 'Francis L. Cardozo,' p.143; The News \& Herald (Winnsboro, S.C.), 10 Nov. 1877 and The Columbia Register(S.C.), 8 Nov. 1877; Deeds and Mortgages in the Books of the Register of Mesne Conveyances of Charleston and Richland Counties, South Carolina (1868-1877) and the books of the Recorder of Deeds, Washington, D.C. (1871-1890); deed of Jos. H. Rainey to F.L. Cardozo in the amount of $\$ 1,250$ for a lot on S. Plain Street in Columbia, in Book J, p.458 (2 July 1873) (Richland County Register of Mesne Conveyances), and deed from Wm. Carrington to Minnie Cardozo in the amount of $\$ 1,000$ for a lot on Sullivan's Island, in Book R16, p.257 (Charleston County Register of Mesne Conveyances); Reports and Resolutions of the General Assembly of the State of South Carolina at the Regular Session, 1872-73, p.395 (as to salaries in 1872) and Reports and Resolutions of the General Assembly of the State of South Carolina $1873-74$, p. 100 (for salaries in 1874); deed dated 12 Aug. 1881 to Elizabeth Hunter in Book Y, p.129 (Charleston County Register of Mesne Conveyances); deeds from F.L. Cardozo and Catherine R. Cardozo to Anna H. Taylor recorded 2 Nov. 1877; Book L, pp.172, 173, Richland County Register of Mesne Conveyances, and foreclosure deed of Cardozo property in Howard University subdivision, in Liber 885, folio 262 (18 April 1878) Recorder of Deeds, Washington, D.C.; deed from Joseph Morris to Minnie H. and Francis L. Cardozo in Liber 1192, folio 253 (21 July 1886) Recorder of Deeds, Washington, D.C..

80. Eslanda Robeson Papers, Moorland-Spingarn Collection, Family Papers, Box 1; letter cited in Farley, 'Francis L. Cardozo,' p.141; D.H. Chamberlain to F.L. Cardozo, 21 Aug. 1893); D.H. Chamberlain to President William McKinley, March 1897, (relative to possible diplomatic appointments for Cardozo) Eslanda Robeson Papers, Family Papers, Box 1, and D.H. Chamberlain to Secretary of Treasury C.J. Folger, 24 Apr. 1882, quoted in Farley, 'Francis L. Cardozo,' p.144; The People's Advocate (Washington, D.C.), 17 May 1879 and 6 Oct. 1883; see Proceedings of the National Convention of Colored Men Held in the City Syracuse, New York, pp.4, 29 (Wilmington, Delaware: Scholarly Resources, 1970 [1864]) (Cardozo represented Connecticut at this meeting that included such leading men as Frederick Douglass and John M. Langston and was elected one of the vice presidents); The People's Advocate (Washington, D.C.), 8, 15, Dec. 1883, 1 Jan., 1 Mar. 1884.

81. William J. Simmons, Men of Mark, Eminent, Progressive and Rising (Cleveland: G.M. Rewell \& Co., 1887), p.430; 'Report of the Secretary of State,' in Reports and Resolutions 1871-72, p.193; The Washington Bee, 13 Oct. 1888, 29, 27 June 1891, 4 July 1888, 29 June 1889, 6 Dec. 1890, 20 June 1891, 9 Apr. 1892, 25 Nov. 1893, 3 Feb. 1894, 16 May 1896; Colored American (Washington, D.C.), 17 Feb. 1894, 20 June, 25 July 1903, and The Washington Post, 23 July 1903; The State (Columbia, S.C.) 18 Mar. 1906.

82. Simkins and Woody, p.145; The Columbia Register (S.C.), 5 Apt.1878; Edmund L. Drago, Hurrah for Hampton (Fayetteville: University of Arkansas Press, 1998), pp.xi, 57, 59, 62; Burke, 'The Radical Law School,' pp.106-7.

83. Christopher Waldrep, Roots of Disorder: Race and Criminal Justice in the American South 1817-1880 (Urbana: University of Illinois Press 1998), p.173. 